\title{
7. JURASSIC CORAL GENERA FROM ODP SITE 639, ATLANTIC OCEAN, WEST OF SPAIN1
}

\author{
Gabriel A. Gill, CNRS (UA 12), Institut de Paléontologie, Muséum National d'Histoire Naturelle, Paris, France \\ and \\ Jean-Paul Loreau, ${ }^{2}$ Laboratoire de Géologie, Muséum National d'Histoire Naturelle, Paris, France
}

\begin{abstract}
Twenty-three Jurassic corals from ODP Hole 639D are illustrated, described, and tentatively assigned to genera, from which a Late Jurassic age (Tithonian?) is suggested. Facies and sediment analyses indicate a soft-substrate habitat and that the bulk of the micrite seems to have been calcite originally. The corals, mostly colonial, are rather diversified, with a strong representation of stylinid and pennular forms. A single pennular colony from Hole 639C is also discussed. The enumerated taxa are Pseudocoenia sp., Stylosmilia cf. pumila, Stylosmilia sp., Enallhelia sp., cf. Dimorphastraea sp., Latomeandridae, Fungiastraea sp., Trocharea sp., Microsolenidae, cf. Dermosmilia sp., Calamophylliopsis(?) sp., cf. Thecosmilia sp., Lochmaeosmilia sp., and Intersmilia sp.
\end{abstract}

\section{INTRODUCTION}

At Ocean Drilling Program (ODP) Site 639, six holes were drilled in a carbonate platform of Late Jurassic age. An interval of about $100 \mathrm{~m}$ of limestone, interbedded with sandstone and shale and overlain by dolomite, was cored at Hole 639D $\left(42^{\circ} 8.06^{\prime} \mathrm{N}, 12^{\circ} 15.3^{\prime} \mathrm{W}\right)$.

Thin sections of eleven cores from this interval (Cores 103639D-3R through 103-639D-13R) contain scattered coral fragments. Attribution of these fragments to structural groups or genera extends known Jurassic coral distribution to this new area. The corals' fragmented condition and the limitations imposed by the thin-section planes precluded specific determination; therefore, the corals are treated here mostly at generic and suprageneric levels. Because the tentative character of these determinations does not allow precise dating, a thorough faunistic comparison with other regions is not justified.

Most of the observed genera are known to have existed during the Middle and Late Jurassic with, in several cases, possible extension into the Early Cretaceous. Stylosmilia pumila (Quenstedt) is attributed to only the Late Jurassic. A latest Jurassic age is not contradicted by the Hole 639D coral assemblage.

The vertical distribution of the corals in Hole 639D is episodical. They occur rarely at the base of the hole as oncoid nuclei (Cores 103-639D-11R through 103-639D-13R) and as debris in Cores 103-639D-7R and 103-639D-8R. These rare occurrences of abraded round bits of colonies indicate transport. Within Cores 103-639D-4R and 103-639D-5R, the corals become common and are accompanied by sponges (mainly calcareous) and echinoderms (Table 1). In some thin sections corals constitute the majority of the fauna, whereas calcareous sponges predominate in others. The corals are often highly corroded and thoroughly bored, which indicates in-situ development followed by bioturbation. As a whole, the corals do not seem to have belonged to reef environments but rather were dwellers of soft, muddy substrates. Enallhelia, Stylosmilia, Lochmaeosmilia, and flat pennular colonies (microsolenids and others) are typical of a muddy, relatively calm sea bottom.

Of the 23 different coral fragments discussed herein, 11 show a pennular pattern, six belong to the Stylinidae (Enallhelia and

\footnotetext{
${ }^{1}$ Boillot, G., Winterer, E. L., et al., 1988. Proc. ODP, Sci. Results, 103: College Station, TX (Ocean Drilling Program).

2 Present address: Centre des Sciences de la Terre, Université de Bourgogne et CNRS (UA 157), Dijon, France.
}

Stylosmilia), and the remaining six are other types (Thecosmilia, Lochmaeosmilia, cf. Dermosmilia sp., Pseudocoenia, cf. Calamophylliopsis, and Intersmilia). The samples, though limited, reflect the importance of the pennular and stylinid structures in the rather diversified coral assemblage. We therefore present diagrams that illustrate these structures in space to aid in their recognition in thin sections (Figs. 1 and 2).

\section{DESCRIPTIONS}

Descriptions are of thin-section samples, unless otherwise noted.

$$
\begin{gathered}
\text { Sample 103-639D-4R-1, 31-34 cm (Piece 5) } \\
\text { Fungiastraea sp. } 1 \\
\text { (Pl. 1, Fig. 1) }
\end{gathered}
$$

This sample has three fragments of a single(?) small thamnasteroid colony. The major fragment in transverse view shows portions of four corroded calices. Septa are mostly compact or with restricted porosity in the adaxial zone. They are pennular, with pennulae rims highly upturned. Dissepiments are thin, numerous, and diagonal in tangential section. The septa unite at their inner ends. The colony seems to have been rather flat. Though the presence or absence of several characteristic elements (columella, synapticulae, and wall) can not be confirmed, the coral may be tentatively assigned to the genus Fungiastraea, previously described mainly under the name Thamnasteria. Similar Jurassic colonies are recorded from Portugal, France, Switzerland, England, Yugoslavia, Poland, and Rumania and dated as Oxfordian, Kimmeridgian, Tithonian, and possibly Callovian. For references, see Morycowa (1974, p. 476-478) and Roniewicz (1976, p. 98-99, pl. 29, figs. 2a-2c).

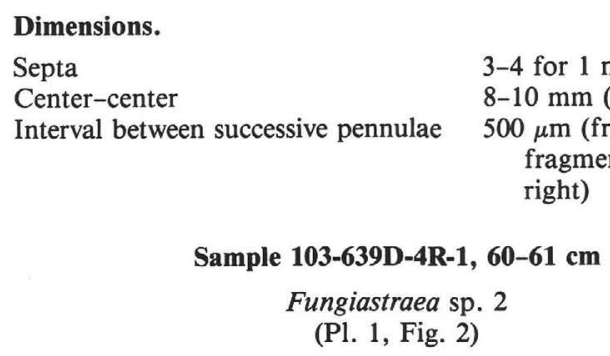

This thamnasteroid colony, represented by a more or less transverse view of an elongate fragment on two sides of the slide, shows parts of three calices. The specimen is comparable to that of Sample 103-639D4R-1, 31-34 cm (see preceding text; Pl. 1, Fig. 1). It shows, however, more perforation at the adaxial zone and toward the periphery. Septa unite, and dissepiments are thin and abundant.

\section{Dimensions.}

Septa

Center-center

3 for $1 \mathrm{~mm}$

6-7 mm 
Table 1. Biofacies units and locations of corals and sponges in Hole 639D.

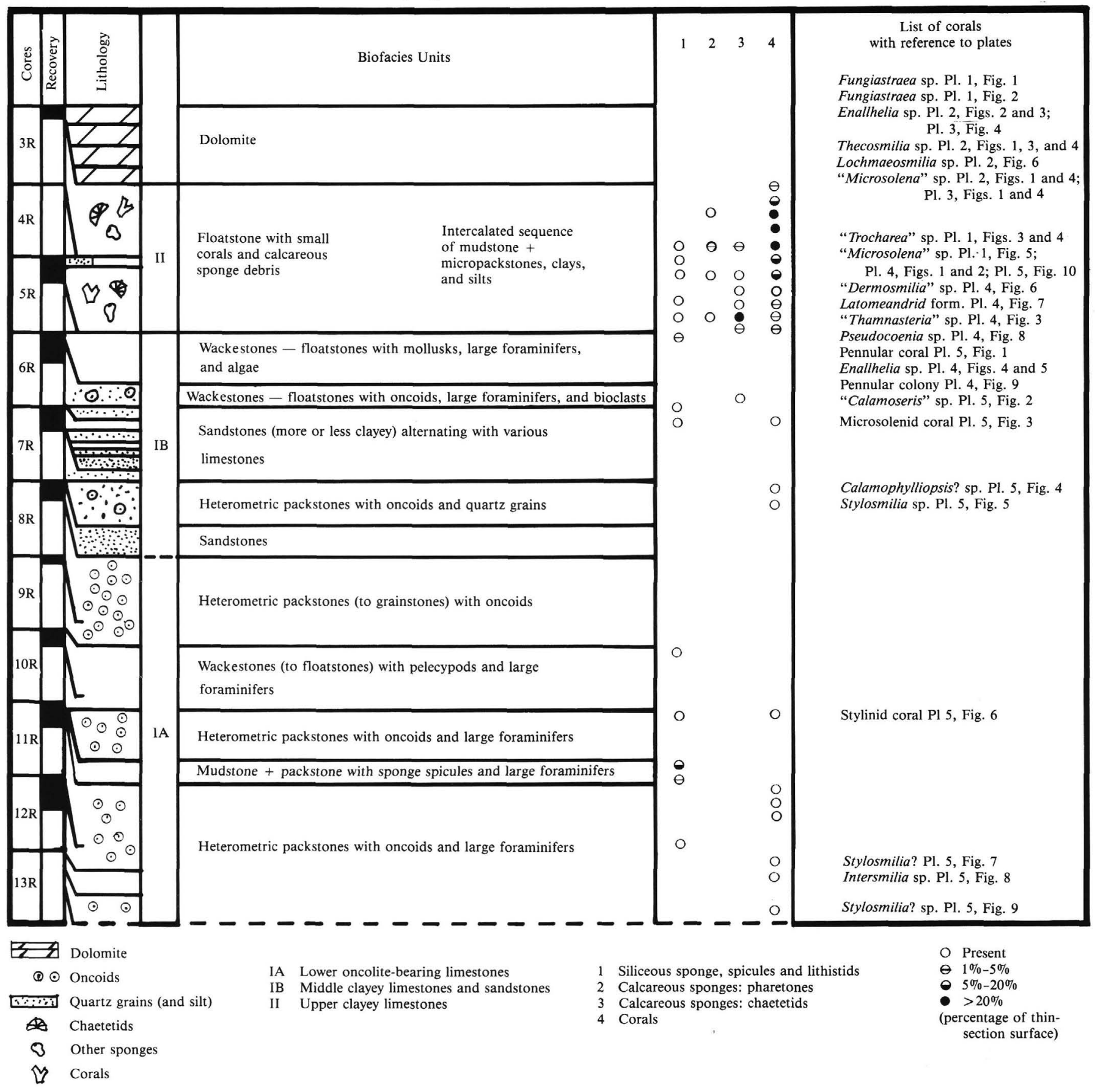

Sample 103-639D-5R-1, 22-23 cm

(Surface of Polished Core) Sample 103-639D-5R-1, 21-24 cm

Trocharea sp.

(PI. 1, Figs. 3 and 4)

Though we show separate illustrations of these two samples, we assume that both represent one single specimen, of which Plate 1, Figure 3, is a longitudinal median section and Plate 1, Figure 4, a longitudinal peripheral one. This specimen is a small, attached solitary coral with perforate septa and pennulae with upturned rims. There is less perforation at the periphery (Pl. 1, Fig. 4). Dissepiments are abundant and inclined; synapticulae are probably present. The wall region is thickened, yet this thickening seems secondary. The upper (calical) end of the coral is convex. The specimen is slightly corroded on the left-hand side, and Plate 1 , Figure 4, shows a truncated and slightly concave surface. The coral is attached to a hardened substrate by a long cylindrical pedicle (one-third of the total height) that gradually widens to form a large turbinate skeleton.

This form may be assigned to genera currently named Leptophyllia, Trocharea, Trochoplegma, or Trochoplegmopsis, recorded from the Middle and Upper Jurassic. The septal density, general outline, and dimensions generally coincide with Leptophyllia spinosa Koby from the Oxfordian-Kimmeridgian of Moulin du Gaio, Portugal (Koby, 1905, p. 98 , pl. 25, figs. 12 and 13). By its septal density, the coral may also correspond to Trochoplegmopsis gregori (Koby) from the early Kimmeridgian of Topalu, Romania (Roniewicz, 1976, p. 96, pl. 27, figs. 1-3). 

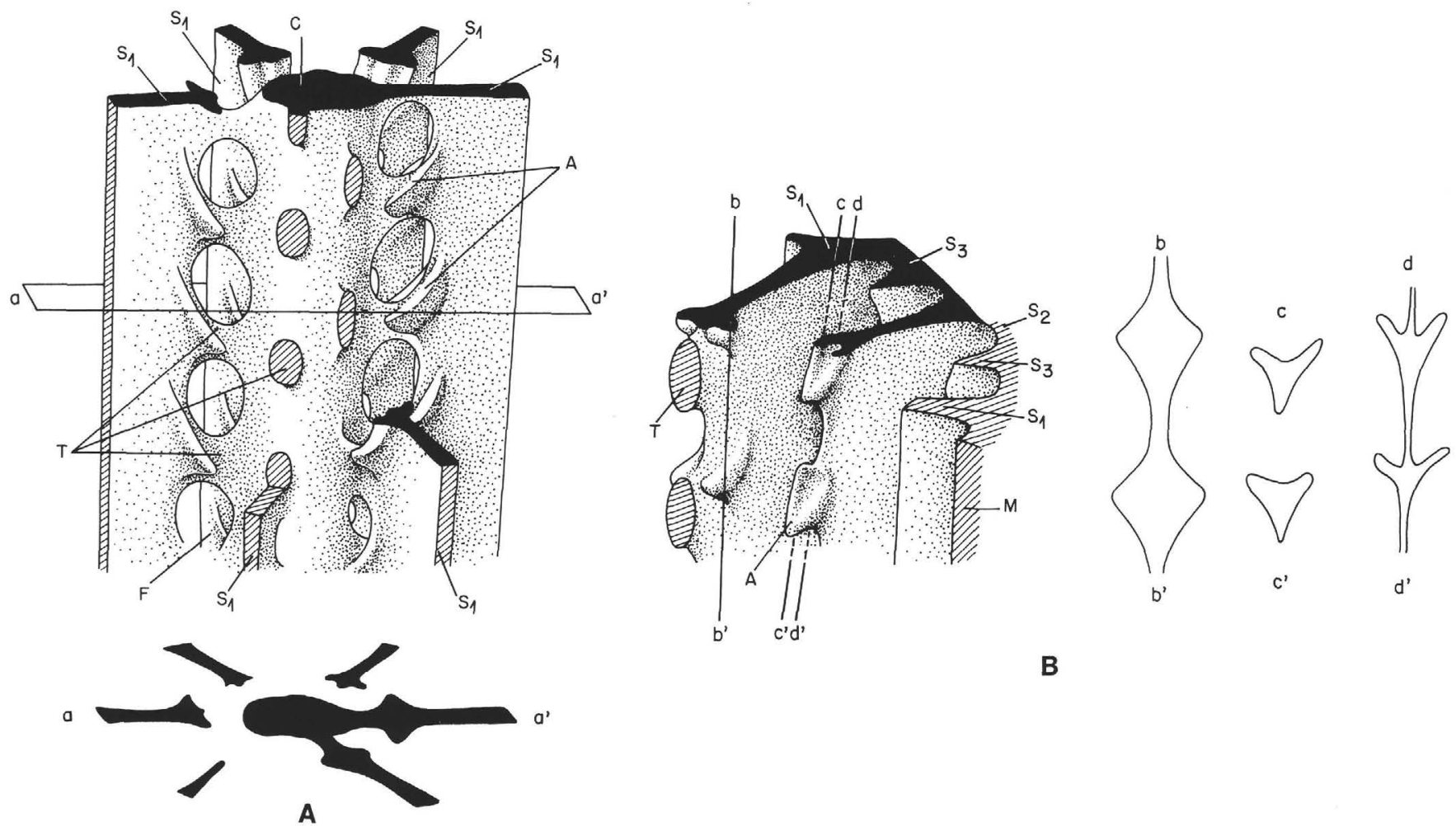

Figure 1. Schematic diagram of the inner margins of the septa within a Stylinid calice (modified after Gill, 1977). $\mathrm{A}=$ auricula, $\mathrm{C}=$ columella, $\mathrm{F}=$ pore, $\mathrm{M}$ = wall, $\mathrm{S}$ = septum, $\mathrm{T}$ = septum-columella connecting rod. A. Relationship of primary (first cycle) septa (S1) to the columella (central pillar), pores, and auriculae. Transverse sections are shown in black across the top and at the bottom for section a-a' ${ }^{\prime}$. B. Disposition of the auriculae within second cycle septa (S2). A transverse section is shown in black along the top and in longitudinal sections $\left(b-b^{\prime}, c-c^{\prime}\right.$, and $\left.d-d^{\prime}\right)$ to the right of the figure.

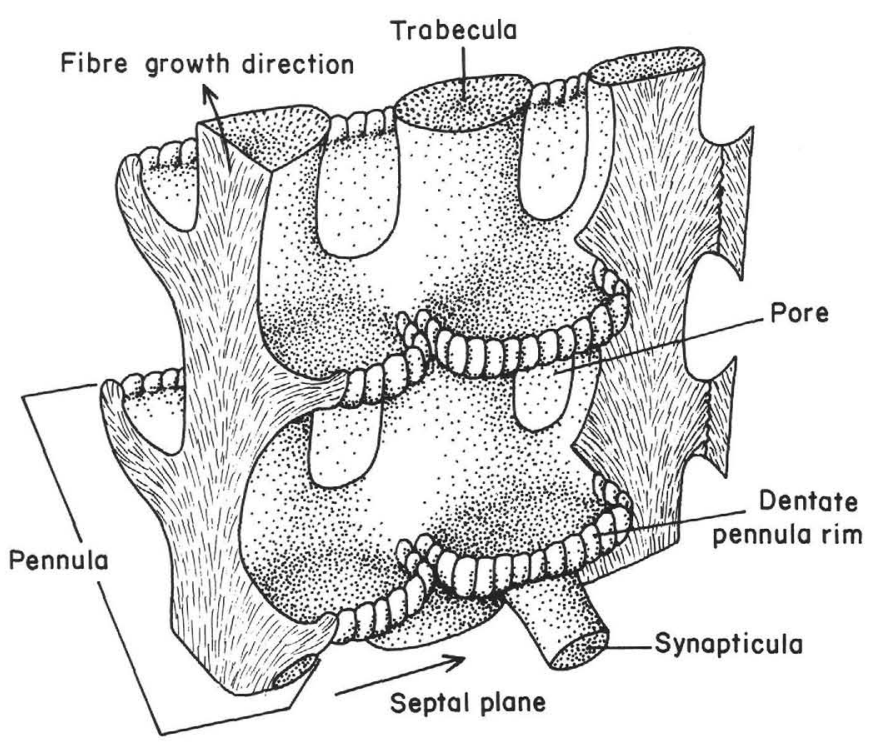

Figure 2. Diagram of portion of a microsolenid coral septum. The orientation of fibers within the trabeculae is shown by radial and tangential-longitudinal sections. On the face of the septum, pennulae form paired ledges that are arranged in discontinuous series (menianae) at right angles to the trabeculae. The pennulae may be at the same level (as depicted in here) or offset vertically (mi-pennular) and concave upward, with rounded teeth along the curved outer rims. The septal pores are between the vertical trabeculae and the laterally joined pennulae (menianae). (Modified after Gill and Coates, 1977.)

\section{Dimensions.}

$\begin{array}{ll}\text { Height } & 11 \mathrm{~mm} \\ \text { Width } & 11 \mathrm{~mm} \\ \text { Diameter of pedicle } & 1-2 \mathrm{~mm} \\ \text { Septa } & 5 \text { for } 2 \mathrm{~mm} \\ \text { Interval between successive pennulae } & 500 \mu \mathrm{m}\end{array}$

Discussion. Some ecological interpretations can be drawn from Plate 1 , Figure 3 . The coral is in life position and shows little sign of perturbation. At an early stage, the pedicle became unbalanced to the left and then readjusted its growth to the right. This happened only once and was not caused by wave or current action but by slight slumping in the substrate or from the touch of an organism. The sediment is very fine grained. Plate 1, Figure 4, shows worms and foraminifers encrusting the lower surface of the coral. These conditions suggest a growth environment that was well sheltered and not shallow.

\section{Sample 103-639D-4R, CC (7-9 cm) \\ (Pls. 2 and 3)}

This sample yielded three thin sections; two of the polished surfaces were photographed before being processed into slides (Pl. 2, Fig. 4, and Pl. 3, Fig. 1). Altogether, there are some 10 different coral fragments in this specimen, but only the major ones will be discussed here.

Enallhelia sp. 1

(Pl. 2, Figs. 1, 2, 4, and 5, and Pl. 3, Figs. 1 and 4)

The species of this genus form slender bushes with slim, flattened, and elongated branches. Alternating calices, which as a rule lie in one plane, occur on the opposing narrow sides of the branches (Pl. 5, Fig. 11). Enallhelia is present in three successive sections in transverse view. We suppose the oldest level to be the one shown in Plate 2, Figures 1 and 2. The right-hand calice is mature, whereas the one on the left is an early stage, being narrower, with septa hardly developed. This level would correspond to the section $a-a_{1}$ in Plate 5, Figure 11. Plate 2, Figures 4 
and 5, show a later stage, when the left calice had also matured. Both calices display a perfect hexameral symmetry, with 24 septa in three size orders, 6-6-12. Claviform sections of auriculae are well defined. The semilongitudinal aspect of the lower left-hand part of the left calice gives the auriculae their arrowlike aspect. The elongate columella is seen in the calice on the right (see also Pl. 4, Fig. 4; Gill, 1977, pl. 1, fig. 24). Sections of subhorizontal dissepiments are visible in the right calice. The plane of this section corresponds to section $b-b_{1}$ in Plate 5, Figure 11. In Plate 3, Figures 1 and 4 , the coenosteum appears asymmetrically thickened, probably because of the oblique section. The left calice seems truncated, yet it is probably intact with the corroded appearance resulting merely to the curved exterior position of the sectioned calice. This plane would correspond to section $\mathrm{c}-\mathrm{c}_{1}$ in Plate 5, Figure 11.

The sequential views of the left calice in the three sections display the normal evolution of calice growth in Enallhelia from an initial central position, inclining outward to the outer limit. Development in a single plane and alternations in budding are confirmed by the three levels. Costae are not seen, most probably obscured by the stereome or eroded from the somewhat-leached surface. This specimen is rather similar to the Enallhelia sp. 2 described from Sample 103-639D-5R-2, 97-99 cm (Pl. 4, Figs. 4 and 5).

\section{Dimensions. \\ Greatest width of branch \\ $5.6-7.8 \mathrm{~mm}$ \\ Smallest width of branch \\ $2.7-4.0 \mathrm{~mm}$ \\ Internal diameter of calices \\ $0.6-2.1 \mathrm{~mm}$ \\ Septa (in three size orders, 6-6-12)}

\section{cf. Thecosmilia sp.}

(Pl. 2, Figs. 1, 3, and 4)

A transverse section of a coral with montlivaltid affinities is shown magnified in Plate 2, Figure 3. Modified by alteration, the septal aspect is not sufficiently reliable. The compound nature of the coral suggests the Jurassic genus Thecosmilia, but its assignment to other montlivaltid genera may also be possible. For instance, Complexastrea carpathica Morycowa from the upper Tithonian of Poland (Morycowa, 1974, p. 470-472) has similar dimensions.

\section{Dimensions. \\ Short diameter \\ Septa on the periphery \\ 7 mm (Pl. 2, Fig. 3) \\ Dissepiments between septa on the periphery \\ Density of carinae \\ 12 for $5 \mathrm{~mm}$ \\ 2-4 for $1 \mathrm{~mm}$ \\ 2-3 for $1 \mathrm{~mm}$}

\section{Lochmaeosmilia sp.}

$$
\text { (Pl. 2, Fig. 6) }
$$

A transverse section of a cylindrical branch has the following characteristics: small diameter, $1 \mathrm{~mm}$; small number of septa, $10(? 12)$ in two orders; occasional uniting of major septa at the adaxial zone; parietal columella; archaeotheca; absence of costae; and septal ornamentation of few prominent spines.

Colonies of slender branches, $1 \mathrm{~mm}$ or less in diameter, with similar characteristics are common in the Middle Jurassic (Bathonian, Callovian) and later, under different generic names: mainly Eunomia and Lochmaeosmilia, but also Stylosmilia, Calamophyllia, and Halysitastraea. They occur in France and England (Bathonian), India, Madagascar, and Israel (Callovian), Ethiopia (Callovian-Oxfordian?), Columbia (Kimmeridgian?), and Czechoslovakia (Tithonian).

Usually this epithecate coral forms dense banks of hemispherical colonies, which seem to have thrived on a soft substrate, exposed to fine bioclastic sedimentation. The corallites are commonly coarsely crystallized, and the calical aspect may be obtained only from a thin superficial film or at the contact of lithophage borings. This presence of an isolated section is surprising for a form that usually builds dense masses of tubes (from 60 to more than 300 per $\mathrm{cm}^{2}$ ). For references see Wells (1943, p. 48-49) and Alloiteau (1958, p. 66-68).

\section{cf. Microsolena sp.}

Under this name we describe a number of sections that display the pennular structure typical of microsolenid corals. Nevertheless, data are

not sufficient for a precise generic determination and the name Microsolena is used merely as a reference.

The largest colony within the slab is seen in all three thin sections (Pl. 2, Figs. 1 and 4; Pl. 3, Figs. 1-4). Detailed magnified views are shown in Plate 3, Figures 2 (polished surface) and 3 and 4 (thin sections). The profiles of the colony are highly undulating and correspond to heavy erosion of the specimen, apparently resulting from borers. Two other views of similarly bored microsolenid colonies may be seen in Plate 1, Figure 5 (Sample 103-639D-5R-1, 25-29 cm) and Plate 5, Figure 10 (Sample 103-639D-5R-1 [Piece 4, 26-29 cm]). Analysis of growth directions (white arrows) in Plate 3, Figure 4, shows that the thin elongate profile has been carved out of a much larger and more voluminous mass. Recrystallization is total; however, the molecular transformation from aragonite to calcite was progressive because the original crystal orientations have been preserved. This can be deduced by comparing the polished surface to the thin section (PI. 3, Figs. 2 and 3). It can be roughly stated that fibers in a pennular structure are mostly vertical along the trabeculae and usually horizontal in the pennulae (but not in the peripheral teeth, where they are again ascendent) (see Fig. 2; Gill, 1982 , pl. 3, figs. 1 and 2). On a polished surface, crystals cut perpendicular to the c-axis appear dark; they appear transparent when cut parallel to the c-axis. Plate 3, Figure 2, shows a polished surface (the same as in Pl. 3, Fig. 1) where the pennular edges in radial section appear as dark rows of "bananas"; trabeculae and pores can not be discerned. The same area in thin section (Pl. 3, Figs. 3 and 4) shows all the sectioned skeletal elements as transparent. This kind of recrystallization is common within Jurassic corals, and thus, the true extent of a skeleton cannot be deduced from a polished surface unless it has been successfully stained.

Dimensions.

Length of pennular rims (radial $280 \mu \mathrm{m}$ section)

Long and short axes of pores $\quad 160$ and $80 \mu \mathrm{m}$

Interval between successive rows of $\quad 300-360 \mu \mathrm{m}$ pennulae

Thickness of trabeculae $\quad 120 \mu \mathrm{m}$

\section{Sample 103-639D-5R-1, 26-29 cm}

cf. Microsolena sp. 2

(Pl. 5, Fig. 10, and Pl. 4, Figs. 1 and 2)

A typical microsolenid colony fills the entire thin section (Pl. 5, Fig. 10) and also figures in Sample 103-639D-5R-1, 25-29 cm (Pl. 1, Fig. 5). Apparently, active boring has given the coral a fanciful appearance of branches and appendices. The skeleton is entirely recrystallized into coarse crystals; in places it may be micritized. Plate 4, Figure 1, shows a detail in longitudinal section in which different elements can be discerned: pennular rims aligned in menianae, pennular rims upturned, alternation in pennular levels, synapticulae, dissepiments, and various dimensions. Plate 4, Figure 2, shows a detail of two joint pennular rims ("bananas") with two sections of synapticulae-one at the left end and the other with a narrower section just below the pennular junction (for similar illustrations see Gill, 1967, pl. 10, figs. 1a and 1b; Gill, 1968, pl. 64, fig. E3, pl. 65, fig. E1, and pl. 66, fig. 1).

\section{Dimensions.}

Distance between septa

Interval between successive rows of pennulae

Length of pennular rims (in radial section)

Width of pennulae (in tangential section)

Diameter of synapticulae

\section{Sample 103-639D-5R-2, 60-62 cm}

\section{cf. Dermosmilia sp.}

$$
\text { (Pl. 4, Fig. 6) }
$$

This fragment in a transverse plane suggests part of a branch belonging to a phaceloid colony. Poor preservation does not permit precise attribution for this nonpennular coral. As possible references for comparison we note Calamophyllia flabellum Bl. in Koby (1905, pl. 12, fig. 1), 
Rhabdophyllia variabilis Koby in Koby (1905, pl. 13, figs. 1-6), Dermosmilia sp. in Roniewicz (1976, pl. 17, fig. 4).

\section{Dimensions.}

Diameter

Septal density

\section{about $7 \mathrm{~mm}$}

2-3 for $1 \mathrm{~mm}$

\section{Latomeandrid Coral}

$$
\text { (Pl. 4, Fig. 7) }
$$

The septa of a pennular coral fragment within a mud-coated grain seem partly perforate with slightly upturned pennular rims in tangential section. Dissepiments are present. Synapticulae are not evident in this small section. The coral may be related to a Latomeandrid genus.

\section{Dimensions.}

Interval between successive pennulae $260 \mu \mathrm{m}$

Distance between neighboring septa $330 \mu \mathrm{m}$

\section{Sample 103-639D-5R-2, 62-70 cm}

\section{cf. Dimorphastraea sp.}

(Pl. 4, Fig. 3)

This is a tangential oblique(?) section through a small fragment of pennular pattern. The septa, being compact, resemble those within corals such as Dimorphastraea and certain Thamnasteria (cf. Gill, 1982, pl. 3, fig. 1; Roniewicz, 1982, pl. 60, fig. 2).

The septa probably appear much thicker because of the oblique section. The "pores" in the crystallized lower part suggest the presence of dissepiments. Only the vertical intervals between pennular levels may be considered as reliable dimensions; they are $300 \mu \mathrm{m}$ wide.

\section{Sample 103-639D-5R-2, 63-65 cm}

\section{Pseudocoenia sp.}

(Pl. 4, Fig. 8)

A very limited view in transverse plane is shown of a half of a calice. It seems to constitute part of a plocoid colony reminiscent of Cryptocoenia or Pseudocoenia. The number of septa in the half calice is six in two size orders, which gives 12 septa for the entire calice $(6+6)$. This is a common number for these forms. Reference is made to Pseudocoenia slovenica Turnšek from the upper Oxfordian-lower Kimmeridgian in Slovenia, Yugoslavia (Turnšek, 1973, p. 20 and 83, Pls. 4 and 5) and from the upper Oxfordian and lower Kimmeridgian in Romania (Roniewicz, 1976, p. 49, pl. 5, fig. 5), where the calice diameter is very small (around $1 \mathrm{~mm}$ ), as it is in this specimen.

\section{Sample 103-639D-5R-2, 94-97 cm \\ Pennular Coral \\ (Pl. 5, Fig. 1)}

This oblique tangential section in a pennular colonial coral shows compact septa, but other data cannot be discerned from the specimen.

\section{Dimensions.}

Distance between successive pennulae

\section{Sample 103-639D-5R-2, 97-99 cm \\ Enallhelia sp. 2 \\ (Pl. 4, Figs. 4 and 5)}

The section passes through two opposing calices in a plane approximating transverse cut for one and a longitudinal cut for the other. Thus, the auriculae display typical claviform and bifurcate aspects in the transverse view and have a claviform and arrowlike appearance in the longitudinal view. The plane of this section corresponds to the suggested section d- $\mathrm{d}_{1}$ in Plate 5, Figure 11. A flat and elongate columella seems to be typical of this genus (see also Pl. 2, Fig. 5; Mori, 1963, pl. 23, fig. 3; Gill, 1977, pl. 1, fig. 24). Some costae are seen on the narrower side of the wall (Pl. 4, Fig. 4); costae have a general tendency to disappear as the wall thickens. This tapering of the wall is discernable in the longitudinal plane (Pl. 4, Fig. 5).
Dimensions.

Calice external diameter $\quad 1.3-1.6 \mathrm{~mm}$

Costal density

6-7 for $1 \mathrm{~mm}$

The number of septa is about 24 , probably in three size orders (6-6-12).

\author{
Sample 103-639D-5R-3, 42-44 cm \\ Pennular Coral \\ (Pl. 4, Fig. 9)
}

This hemispherical, small pennular colony is poorly preserved and does not merit a structural review. It is, however, interesting to note that it served as a hard base that enabled development of a succession of different invertebrate colonies. Its role as stable substrate for further upbuilding is one often played by shallow pennular colonies, microsolenids, and others.

\section{Dimensions.}

Interval between successive pennulae $\quad 300 \mu \mathrm{m}$

\section{cf. Calamoseris(?)}

\section{(Pl. 5, Fig. 2)}

A mud-coated grain surrounds a pennular microsolenid coral fragment that shows upturned pennular rims, dissepiments, and synapticulae in tangential section. The small distance between neighboring septa (200-250 $\mu \mathrm{m})$ and the considerable interval between successive pennulae (400-480 $\mu \mathrm{m}$ ) suggest an elongate structure of a branching (phaceloid) type-cf. Calamoseris sp. in Gill $(1967$, pl. 5 , figs. 3 and 4$)$ and Dermoseris delgadoi Koby in Roniewicz (1976, pl. 32, figs. 1a and 1b).

\section{Dimensions.}

Width of pennulae

$200 \mu \mathrm{m}$

Distance between neighboring septa $200-250 \mu \mathrm{m}$

Distance between successive pennulae

\section{Sample 103-639D-7R-1, 71-75 cm \\ Microsolenid Cora \\ (Pl. 5, Fig. 3)}

An oval, micritized grain of a microsolenid fragment in radial section frames three trabeculae delimiting pores toward the top of the view and parallel menianae composed of uniting concave pennular rims along bottom. The coral skeleton reaches the edges of the grain, which indicates that this particle was not coated.

\section{Dimensions.}

$\begin{array}{ll}\text { Height of pores } & 200 \mu \mathrm{m} \\ \text { Width of pores } & 100 \mu \mathrm{m} \\ \text { Distance between trabeculae } & 200 \mu \mathrm{m} \\ \text { Distance between successive } & 330 \mu \mathrm{m}\end{array}$
menianae

\section{Sample 103-639D-8R-1, 15-19 cm (Piece 3) cf. Calamophylliopsis? (Pl. 5, Fig. 4)}

This is a transverse section of a 3.3-mm-long fragment from the periphery of a calice. The estimated diameter for the entire circular calice is $7.4 \mathrm{~mm}$, with about 77 septa. The septa are compact and thin, with scarce, pointed granulations. Every second septum is thicker and longer. The septothecal wall, here feebly marked, may result from the thickening of vertical dissepiments, which form one or two peripheral rings. The uniform and regular costae are continuous with the septa.

The partial view of this fragment does not permit a well-founded identification. Nevertheless, we propose a comparison with Calamophyllia flabellum and C. ducreti, as described by Koby (1905, p. 84-85), and C. crassa Koby (Geyer, 1955, p. 331) from the Upper Jurassic of Portugal. These species are also described from Upper Jurassic beds in Switzerland, France, Czechoslovakia, and Yugoslavia. Comparison might also be made with Calamophylliopsis stokesi (Edw. and H.), as described by Roniewicz (1966, p. 241-242, Pl. 21, Fig. 5; 1976, p. 76). 
Dimensions.

Density of septa and costae at the 10 for $3 \mathrm{~mm}$ periphery

Sample 103-639D-8R-1, 25-29 cm

Stylosmilia sp. 1

(Pl. 5, Fig. 5)

A transverse section shows a perfectly circular branch with a narrow, undulating elongate columella and thin septa. The auriculae are narrow and not strongly pronounced. The outer surface is eroded; however, traces of the costae, which are in continuity with the septa, are left along a narrow sector (about $300^{\circ}-330^{\circ}$ in the figure). The number of septa, in two size orders, is $20(10+10)$.

For reference sections see Goniocora pumila (Quenstedt 1852) in Lambelet (1968, fig. 79a), Goniocora pumila (Quenstedt) in Turnšek (1973, p. 27-87, pl. 11, figs. 1 and 2), Stylosmilia pumila (Quenstedt 1852 ) in Roniewicz (1976, pl. 8, fig. 1), and Stylosmilia michelini M. Edw. and H. in Gill (1977, pl. 4, figs. 1a, 2, 4, and 4a). The dimensions and the septal number of $S$. pumila given by Lambelet (1968), Turnšek (1973), and Roniewicz (1976) agree with those in this sample. The age assigned to $S$. pumila in the preceding works is late Oxfordian-early Kimmeridgian.

\section{Dimensions.}

Calice interior diameter $\quad 2.4 \mathrm{~mm}$

Calice exterior diameter $\quad 2.8 \mathrm{~mm}$

\section{Sample 103-639D-11R-1, 80-89 cm \\ Stylinid Coral \\ (Pl. 5, Fig. 6)}

The framework of this circular coated grain seems to be a fragment of a stylinid coral. It is interpreted as an intercalical longitudinal section showing auriculae united to a septum in the middle and isolated by the section on the sides.

\section{Dimensions.}

Vertical distance between auriculae $\quad 400 \mu \mathrm{m}$

Width of auriculae $\quad 360 \mu \mathrm{m}$

Sample 103-639D-13R-1, 117-120 cm

cf. Stylosmilia(?)

(Pl. 5, Fig. 7)

A poorly represented calice in this diagonal section may be that of a stylinid (Stylosmilia?). The number of septa is about 20. Primary septa may reach the center (a columella seems to exist).

Dimensions.

Outer diameter of the calice

$2 \mathrm{~mm}$

Sample 103-639D-13R-1, $128-133 \mathrm{~cm}$

\section{Intersmilia $\mathrm{sp}$}

(Pl. 5, Fig. 8)

The characteristics of this transverse diagonal section of a single calice seem to fit the definition of the genus Intersmilia. It may be compared to a young calice of $I$. diaboli Elisášová (1974, Pls. 2-4) from the Tithonian of Stramberk (Moravia, Czechoslovakia). The main characteristics of this species, as given by Eliásová (1974, p. 416), are as follows. High branching (phaceloid) colonies consist of cylindrical corallites with transversal wrinkled epitheca. At a given level the branches show different diameters due to budding. Septal symmetry is radial and hexameral. Primary septa often bend toward each other; two opposing primary septa generally join the center and others may join these two directly or by means of the dissepiments. The $\mathrm{S}_{2}$ are slightly shorter than the $S_{1}$. The $S_{3}$ cover a quarter of the corallite diameter. The $S_{4}$, rudimentary, develop partially within older corallites. In transverse section, the dissepiments are cut into two to four incomplete rings. The wall is septothecal, and numerous abortive septa contribute to its composition. Intracalical marginal budding is common.

The sample studied here shows only one incomplete ring of dissepiments and does not give enough evidence for a septothecal wall.
Dimensions.

Calice external diameter $\quad 2.2 \mathrm{~mm}$

Sample 103-639D-13R-1, 142-146 cm

$$
\text { cf. Stylosmilia sp. } 2
$$$$
\text { (Pl. 5, Fig. 9) }
$$

This transverse section of a thin circular branch is poorly preserved. Essential columella, archaeathecal wall, and costae are recognizable. The septa are in two size orders, and apparently number 20 . Diameter is $1.8 \mathrm{~mm}$. This section is comparable to the one in Sample 103-639D-8R-1, $25-29 \mathrm{~cm}$ (Pl. 5, Fig. 5), which is slightly larger.

\section{Samples 103-639D-5R-2, 75-77 cm and 103-639D-4R-1, 42-44 cm \\ Chaetetidae}

(Pl. 6, Figs. 1 and 2)

Mesozoic Chaetetids are presently considered to be sponges and are thus outside the scope of this paper. They are, nevertheless, briefly commented on here because they are common in Cores 103-639D-4R and 103-639D-5R, often in association with corals. There is a noteworthy difference in skeleton fossilization between Jurassic and Cretaceous Chaetetidae and the Scleractinian corals. The corals have an aragonitic skeleton that usually transforms into calcite. This transformation obliterates the microstructure. Jurassic and Cretaceous Chaetetidae show wellpreserved microstructures within calcitic skeletons. Plate 6, Figure 1, shows the fan-shaped ("jet d'eau") disposition of the fibers in the wall of a specimen from Core 103-639D-5R. A small Chaetetid colony from Core 103-639D-4R is in Plate 6, Figure 2.

According to J.-C. Fischer (pers. comm., 1987), neither Jurassic nor Cretaceous Chaetetids have been recorded to date from reefal bodies. They are common in stratified sediments and often show an adaptation to soft substrates, deposited at some depth.

\section{Sample 103-639C-2R-2, 69-72 cm \\ Microsolenid Coral \\ (Pl. 6, Fig. 5)}

This is a single coral remnant from Hole 639C, which most probably came from a colony. The pattern is that of a microsolenid with porous septa and large pennulae with upturned rims. Dissepiments are abundant, thin, and of diagonal growth between the septa. Synapticulae are present. The observable skeleton seems to be a relic of a larger colony transformed into dolomite. This transformation occurred within the coral to different degrees. Gradually fading ghosts of the skeleton occur in the light gray portion of Plate 6, Figure 5.

Dimensions.

$\begin{array}{ll}\text { Septa } & 2 \text { for } 1 \mathrm{~mm} \\ \text { Interval between successive pennulae } & \text { about } 250 \mu \mathrm{m}\end{array}$

\section{ENVIRONMENTAL INTERPRETATION OF CORAL-BEARING FACIES}

\section{Biosedimentation and Diagenesis}

\section{Coral Distribution throughout Hole 639D in Relation to Microfacies}

The vertical distribution of the corals is variable. They occur as very rare nuclei of oncoids in Cores 103-639D-11R to 103639D-13R (Table 1), as rare debris within the packstones of Core 103-639D-8R, and in a grainstone of Core 103-639D-7R (Sample 103-639D-7R-1, 71-75 cm; P1. 5, Fig. 3). Some rare ghosts are in the dolomite that overlies the limestone in uppermost section of Hole 639D. The general rarity of these occurrences indicate that the location of Hole 639D was remote from the coral areas.

Corals become dominant within the floatstones of Cores 103-639D-5R and 103-639D-4R, occurring in small masses or in fragments associated with various sponges and their debris. We 
shall try to analyze the particular facies within these two cores in terms of paleoenvironment.

\section{Matrix, Organisms, and Debris within the Coral Facies}

The matrix in the coral-bearing wackestones-floatstones of Cores 103-639D-4R and 103-639D-5R shows three types of structures:

1. The dominant structural type is micrite with some recrystallized fine microsparitic debris. Most of this debris seems to have been aragonitic bioclasts initially; other debris consists of calcitized spicules of siliceous sponges (Pl. 6, Fig. 2).

2 . The second structural type is a bioclastic micropackstone with an increase of microdebris in the micrite; $50-\mu \mathrm{m}$-sized pellets may be present (Pl. 6, Fig. 3).

3. The third type, which is not as common, has a clotted or lumpy micritic structure (cf. Cayeux's [1935] "structure grumeleuse") where micritic zones and micropellets(?) have faint boundaries with the surrounding microspar. Other microsparitic patches are probably recrystallized debris (Pl. 6, Fig. 4), interpreted as a result of the diagenesis of soft, poorly individualized pellets or dolomitization-dedolomitization of sediments of the preceding two matrix types.

Foraminifers are present mainly in the first two types of matrix. Anchispyrocyclina is scarce, except within Sample 103639D-5R-3, 13-16 cm; Pseudocyclamina and Trocholina are less common than in lower levels of the sequence. The abundance of slightly clayey mud, small agglutinated benthic foraminifers, and calcitized spicules of siliceous sponges and the presence of calpionellids and fine bivalve shells must be considered in the matrix analysis. These components indicate a muddy, open-ocean environment that does not differ from that suggested for the lower levels of the sequence.

The following organisms are recognized in the larger-size debris fraction: corals, calcareous sponges (Chaetetids, Pharetrones), lithistid sponges, echinoderms-more common than in lower levels and including both surface and irregular mud dwellers (Sample 103-639D-5R-2, 97-99 cm), bivalves (rather common), few gastropods, brachiopods, rare algae, and rare bryozoans and serpulids.

\section{Coral Debris}

One centimeter-sized solitary coral is preserved nearly intact and attached in life position (Sample 103-639D-5R-1, 22-23 cm; Pl. 1, Figs. 3 and 4). All of the other corals are found as fragmented remnants forming millimeter- to centimeter-sized debris. The corals are commonly bored, micritized in places, and etched or reduced to fragments by biological activity. Their carved appearance (see Sample 103-639D-4R, CC (7-9 cm), Pl. 3, Fig. 4, and Sample 103-639D-5R-1, $25 \mathrm{~cm}, \mathrm{Pl}$. 1, Fig. 5, and Pl. 5, Fig. 10) is obviously due to biological activity and not to transport or wave action, in which mutual collisions would produce rounded "wrought" grains and not perforate ones. Many of the corals are encrusted, mainly by serpulids, foraminifers, bryozoans, sponges, or Rhodophyceae. The encrustations may be polyphased (Pl. 4, Fig. 9), with a bindstone texture on a centimeter-size scale. The various kinds of debris were deposited in a muddy, slightly clayey environment where the adapted organisms lived.

\section{Diagenesis}

The sediment, though predominantly muddy, contains scattered shells, lithified organisms, and consolidated patches (Pl. 1, Fig. 3) that are propitious for the settling of larvae and, eventually, for the formation of small colonial or solitary corals.
Synsedimentary lithification is evidenced by open burrows incompletely filled by internal sediments (Sample 103-639D-5R-3, 42-44 cm). The mottled appearance of the micrite associated with microerosion figures (such as millimeter-size cliffs) also suggests the development of a firm ground (Sample 103-639D$5 \mathrm{R}-3,42 \mathrm{~cm}$ ). Some sponges were rapidly lithified; felts of spicules are observed embedded in dark micrite, which forms a clear boundary with the matrix (Sample 103-639D-5R-2, 94-97 cm). Such structures, called tuberoids, result from decay of lithistid sponges and their consolidation by syngenetic carbonate precipitation (Fritz, 1958; Gaillard, 1983).

A comparative study of the recrystallized skeletons of the corals and the surrounding micrite, as external matrix or internal filling, suggests different mineralogical patterns. This examination dismisses disaggregation of aragonitic debris or precipitation of aragonite as an origin for the mud. Within the Chaetetidae, the fine fibrous microstructure is preserved in calcite $(\mathrm{Pl} .6$, Fig. 1). The corals, in contrast, have a sparry mosaic (Pl. 2, Fig. 5, Pl. 3, Fig. 3, and Pl. 4, Figs. 2 and 5), which is a common result of the classic aragonite-calcite transformation. The boundary with the sediment is commonly sharp (Pl. 2, Fig. 5, and Pl. 3, Fig. 4), and the skeletons may preserve the primary directions of growth (Pl. 3, Figs. 2 and 3). If the micrite comes from aragonite, the coral/sediment contact would be effected by the recrystallization. These "field relations" suggest a different mineralogy for the aragonitic corals and the micrite, but whatever the origin, the mud was most probably calcitic and not aragonitic, as is the case in modern environments (Loreau, 1982).

\section{Discussion}

The corals from Hole 639D are small and varied and apparently dwelled upon a muddy substrate together with a variety of other invertebrates. Similar Jurassic assemblages occur in other regions, of which the following are some examples: India (Cutch) (Gregory, 1900), Saudi Arabia (coll. Smithsonian Inst., Washington, DC; Okla, 1986; El-Asa'ad, in press), Israel (Kurnub) (Hudson, 1958); Sinai (Moghara) (Alloiteau and Farag, 1964); southern Tunisia (Beauvais, 1966); Crete (Bonneau et al., 1974); Poland (Balin) (Reuss, 1867); Japan (Somanana Ksmura, Fukushima) (Mori, 1963); Germany (Nattheim) (Becker and Milaschewitsch, 1875-1876); France (Charente-Maritime) (Lafuste, 1957, 1960); and Portugal (Koby, 1905). In the Middle and Late Jurassic, numerous islands periodically emerged in the shallow warm seas. Active erosion provided a large quantity of silt and clay to be deposited over vast areas. Biological proliferation upon and within these muddy substrates is documented, and, as subsidence was often matched by sedimentation, facies repetition in successive strata is encountered throughout thick field sections. Ammonites may be found together with corals, whereas they are absent in coral reefs (Hudson, 1958; Gill et al., 1985). The corals from Hole 639D do not evoke either a reef environment or a foreslope breccia. Their nature, the biological association, and the composition of the matrix indicate an in-situ facies developed from the rapid reworking in place of embryonic colonies, essentially by strong biological activity.

Pennular colonies (Microsolena) were often the pioneers for settlement over muddy bottoms (Pl. 4, Fig. 9). But the presence of various sponges (chaetetids, pharetrones, lithistids) seems to exclude reef formation (Fischer, 1969), which was probably constrained by the depth. The relative importance of infaunal echinoderms, the abundance of siliceous sponges and small agglutinated benthic foraminifers, the presence of calpionellids, and the muddy, slightly clayey matrix are significant. These features indicate a milieu that was not favorable for the formation of massive coral buildups. Instead, such features seem to fit an intermediate environment between intralittoral and bathyal do- 
mains (Gaillard, 1983). Modern equivalent environments, though of poor coral diversity, may be the stable muddy bottoms described by Peres and Picard (1964) in the Mediterranean and the so-called "coralligéne" bottoms; their bathymetry is 50 to $70 \mathrm{~m}$.

Wright (1985) records high production of fine-grained calcitic micrite precipitated on floating masses of algae and in benthic mats in algal nonmarine marshes of Late Jurassic age along the Portugese shore (Vale Verde Beds). On transgressive coastlines, algal marsh deposits were often removed during the transgression in all but the most protected areas. Rosendahl (1985) notes that at the end of the Jurassic, sedimentation in the Algarve (southern Portugal) shows a progressive continental influence. In his opinion, the marly carbonaceous facies rendered the formation of coral reefs impossible.

The age of the corals seems from all the evidence to be Late Jurassic (Tithonian?). Yet, it is worthwhile to note that little is known about Berriasian corals. Morycowa (1968 and pers. comm., 1987) finds typical Tithonian corals in association with calpionellids of early Neocomian age (most probably Berriasian), which could indicate that the Tithonian coral fauna might have passed into the Berriasian without noticeable changes.

\section{CONCLUSIONS}

1. The generic identification suggested for the corals studied in thin section from Hole 639D includes Stylosmilia, Enallhelia, Pseudocoenia, Trocharea, Microsolena, cf. Calamoseris, cf. Dimorphastraea, Fungiastraea, cf. Thecosmilia, cf. Calamophylliopsis, cf. Dermosmilia, Lochmaeosmilia, and Intersmilia.

2. The sampling, though limited, emphasizes the importance of pennular and stylinid corals in the diversified coral collection.

3. The presence of Stylosmilia pumila (Quenstedt) indicates a Late Jurassic age, which does not contradict the presence of the other genera recorded.

4. The occurrence of the corals at Hole 639D is episodical. At the base (Cores 103-639D-13R through 103B-639D-11R, 103B-639D-8R, and 103-639D-7R), the corals are rare, tiny fragments that occur as oncoid nuclei or micritized grains. Their appearance indicates corrosion through transport from small colonies in muddy environments. In Cores 103-639D-4R and 103639D-5R, corals are common and are associated with calcareous and siliceous sponges, echinoderms, agglutinated benthic foraminifers, bivalves, and some calpionellids. They are in situ and although commonly heavily bored, definitely indicate that they were not transported.

5. The microfacies of the corals from Cores 103-639D-4R and 103-639D-5R are characterized by a high content of mud; this mud seems to have been initially calcitic.

6. The corals do not reveal the proximity of a reef environment; rather, they were dwellers of soft muddy substrates below wave activity. In Cores 103-639D-4R and 103-639D-5R, the associated organisms suggest a depth range from 30 to $70 \mathrm{~m}$ below sea level.

\section{ACKNOWLEDGMENTS}

We are indebted to J. G. Lafuste (Paris), E. Roniewicz (Warsaw), D. E. Russell (Paris), and J.-C. Fischer (Paris) for their useful remarks. The photographs were made by D. Serrette, C. Privé-Gill, and M. Destarac. F. Pilard made the drawings. L. Ganon, M. Lemoine, and S. Barta-Calmus helped in thin-section preparation and library research. C. Privé-Gill and J. Maréchal typed the manuscript. This paper was improved by reviews from A. G. Coates, J. W. Wells, and A. W. Meyer. Our sincere thanks are due to all.

\section{REFERENCES}

Alloiteau, J., 1958. Monographie des Madréporaires fossiles de Madagascar. Ann. Geol. Madagascar, 25.
Alloiteau, J., and Farag, I., 1964. Monographie des polypiers Jurassiques d'Egypte. Bull. Inst. Egypte, 39:49-130.

Beauvais, L., 1966. Etude des Madréporaires Jurassiques du Sahara tunisien. Ann. Paleontol., 52:115-152.

Becker, E., and Milaschewitsch, C., 1875-1876. Die korallen der Nattheimer schichten. Palaeontographica, 21:121-244.

Bonneau, M., Beauvais, L., and Middlemiss, F. A., 1974. L'unité de Miamou (Créte-Gréce) et sa macrofaune d'age Jurassique Supérieur (Brachiopodes, Madréporaires). Ann. Soc. Geol. Nord, 94:71-85.

Cayeux, L., 1935. Les Roches Sédimentaires de France; Roches Carbonatées: Paris (Masson).

El-Asa'ad, G.M.A., in press. Callovian hermatypic corals from the Tuwaiq Mountain Limestone of Saudi Arabia. J. Coll. Sci. King Saud Univ., 19(2).

Eliášová, H., 1974. Genre nouveau Intersmilia (Hexacorallia) du Tithonien des Calcaires de Stramberk (Tchécoslovaquie). Cas. Mineral. Geol., 19:415-417.

Fischer, J.-C., 1969. Géologie, paléontologie et paléoécologie du Bathonien du Sud-Ouest de Massif Ardennais. Mem. Mus. Nat. Hist. Ser. $C, 20$.

Fritz, G. K., 1958. Schwammstotzen, Tuberolithe und Schatlbrecien im Weissen Jura der Schwäbischen Alb. Arb. Inst. Geol. Palaeontol. Univ. Stuttgart, 13.

Gaillard, C., 1983. Les biohermes à spongiaires et leur environnement dans l'Oxfordien du Jura méridional. Doc. Lab. Geol. Fac. Sci. Lyon, 90.

Geyer, O. F. 1955. Korallen-faunen aus dem Oberen Jura von Portugal. Senckenbergiana Lethaea, 35:317-356.

Gill, G. A., 1967. Quelques précisions sur les septes perforés des Polypiers mésozoiques. Mem. Soc. Geol. Fr., 106:55-83.

1968. Sur les pennules des Microsolenides (Coraux): étude complémentaire. Riv. Ital. Paleontol. Stratigr., 74:969-986.

1977. Essai de regroupement des Stylines (Hexacoralliaires) d'aprés la morphologie des bords internes de leurs septes. Mem. BRGM, 89:283-295.

1982. A supposed rhythmic mechanical process in coral skeletal growth. In Paleontology, Essential of Historical Geology: Proc. 1st Int. Meet. Modena, 445-465.

Gill, G. A., and Coates, A. G., 1977. Mobility, growth patterns and substrate in some fossil and Recent corals. Lethaia, 10:119-134.

Gill, G. A, Thierry, J., and Tintant, H., 1985. Ammonites calloviennes du sud d'Israël: systématique, biostratigraphie et paléobiogéographie. Geobios, 18:705-751.

Gregory, J. W., 1900. The corals: Jurassic fauna of Cutch. Palentol. Indica, 9(2).

Hudson, R.G.S, 1958. The Upper Jurassic faunas of southern Israel. Geol. Mag., 95:415-425.

Koby, F., 1904-1905. Description de la faune Jurassique du Portugal. Polypiers du Jurassique supérieur. Comun. Serv. Geol. Port.

Lafuste, J., 1957. Le récif corallien de la corne nord de la Pointe du Ché (Séquanien supérieur). Ann. Soc. Sci. Nat. Charente-Maritime, 9: 133-146.

1960. Les apports terrigénes dans les récifs du Séquanien du sud de La Rochelle (Charente-Maritime). Bull. Soc. Geol. Fr., 7: 365-368.

Lambelet, E., 1968. Korallen im korallen-oolith mit besonderer Berücksichtigung der Gattun gen Montlivaltia und Thecosmilia [Dissert.]. Hamburg Univ.

Loreau, J.-P., 1982. Sédiments aragonitiques et leur genése. Mem. Mus. Nat. Hist. Ser. C, 47.

Mori, K., 1963. Geology and paleontology of the Jurassic Somanakamura Group, Fukushima Prefecture, Japan. Sci. Rep. Tohoku Univ. Ser. 2, 35:33-65.

Morycowa, E., 1968. Sur les calcaires exotiques á Madréporaires dans les environs de Lac de Roznow (Carpathes polonaises de Flysch). Ann. Soc. Geol. Pol., 38:19-22.

1974. Hexacorallia d'un bloc exotique de calcaire tithonique à Wazniki de Wadowice (Carpathes Polonaises occidentales). Acta Geol. Pol., 24:457-484.

Okla, S. M., 1986. Litho- and microfacies of Upper Jurassic carbonate rocks outcropping in central Saudi Arabia. J. Pet. Geol., 9:195-206.

Peres, J. M., and Picard, J., 1964. Nouveau manuel de bionomie benthique de la Mer Méditerranée. Rec. Trav. Stn. Mar. Endoume, 47. 
Reuss, A. E., 1867. Die Bryozoen, Anthozoen und Spongiarien des Braunen Jura von Balin bei Krakau. Denkshr. Akad. Wiss. Wien, 27:1-26.

Roniewicz, E., 1966. Les Madréporaires du Jurassique supérieur de la bordure des Monts de Sainte-Croix, Pologne. Acta Palaeontol. Polonica, 11:157-264.

1976. Les Scléractiniaires du Jurassique supérieur de la Dobrogea Centrale, Roumanie. Palaeont. Polonica, 34:17-121.

, 1982. Pennular and non-pennular Jurassic Scleractinianssome examples. Acta Palaeontol. Polonica, 27:157-193.

Rosendahl, S., 1985. Die oberjurassische Korallenfazies von Algarve (Südportugal). Arb. Inst. Geol. Palaeontol. Univ. Stuttgart, 82:1125 .
Turnšek, D., 1973. Zgornjejurske korale iz juzne Slovenije (Upper Jurassic Corals of Southern Slovenia). Razp. Slov. Akad. Znan. Umet., 15:1-121.

Wells, J. W., 1943. Palaeontology of Harrar Province, Ethiopia. 3. Jurassic Anthozoa and Hydrozoa. Bull. Am. Mus. Nat. Hist., 82:3154.

Wright, V. P., 1985. Algal marsh deposits from the Upper Jurassic of Portugal. In Toomey D. F., and Nitecki, M. H. (Eds.), Paleoalgology: Heidelberg (Springer-Verlag), 330-341.

Date of initial receipt: 6 April 1987

Date of acceptance: 19 October 1987

Ms 103B-150 


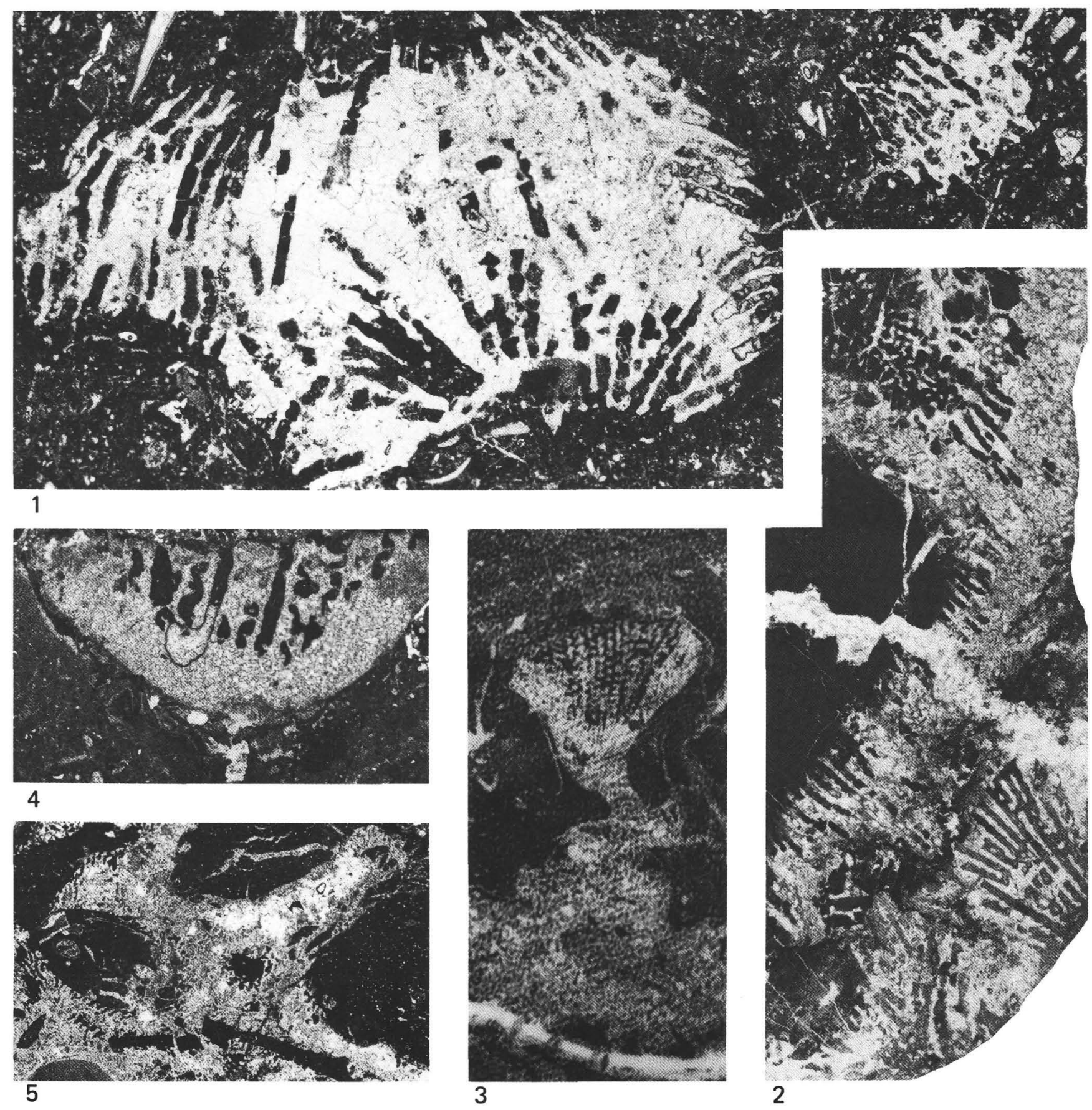

Plate 1. 1. Thin-section photomicrograph of Sample 103-639D-4R-1 (Piece 5, 31-34 cm). Fungiastraea sp. 1. The skeleton on the left is seen in a transverse plane; the smaller fragment on the right, in longitudinal plane, seems to belong to the same colony and would suggest a flat growth habit. $(10 \times)$ 2. Thin-section photomicrograph of Sample 103-639D-4R-1, 60-61 cm. Fungiastraea sp. 2. (6×) 3. Cut surface of Core 103-639D-5R-1, $22-23 \mathrm{~cm}$. Longitudinal median section of Trocharea sp. in life position. $(3 \times)$ 4. Thin-section photomicrograph of Sample 103-639D-5R-1, 21-24 $\mathrm{cm}$, of the same specimen of Trocharea sp. in Figure 3. The section is longitudinal peripheral. $(10 \times)$ 5. Thin-section photomicrograph of Sample 103-639D-5R-1, 25-29 cm. Microsolena sp. 2 colony with heavy boring. The same colony is also in Plate 4, Figures 1 and 2, and Plate 5, Figure 10. $(3 \times)$ 


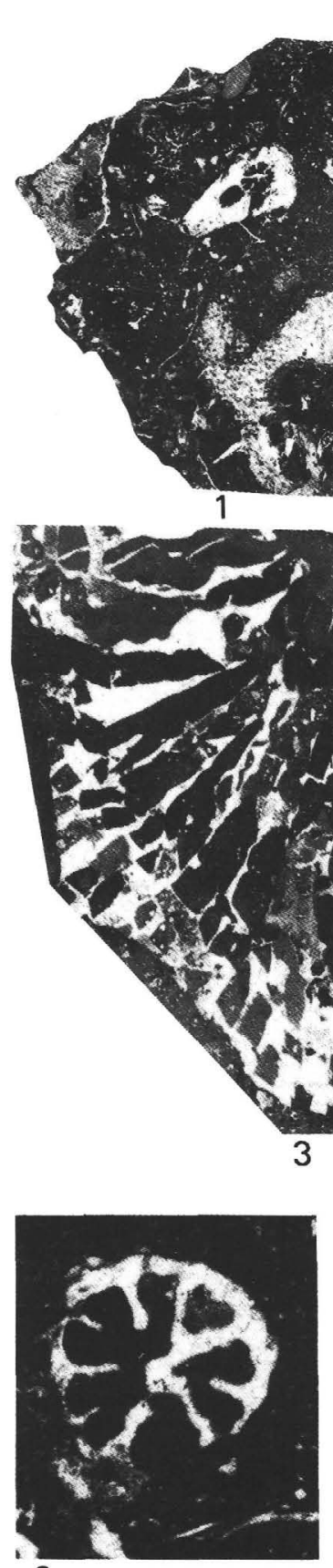

6

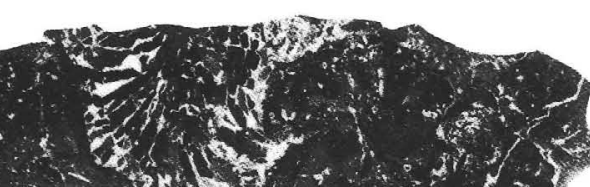

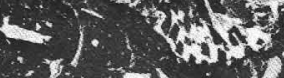

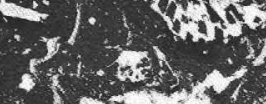

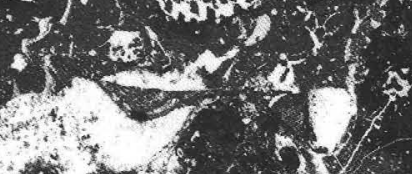
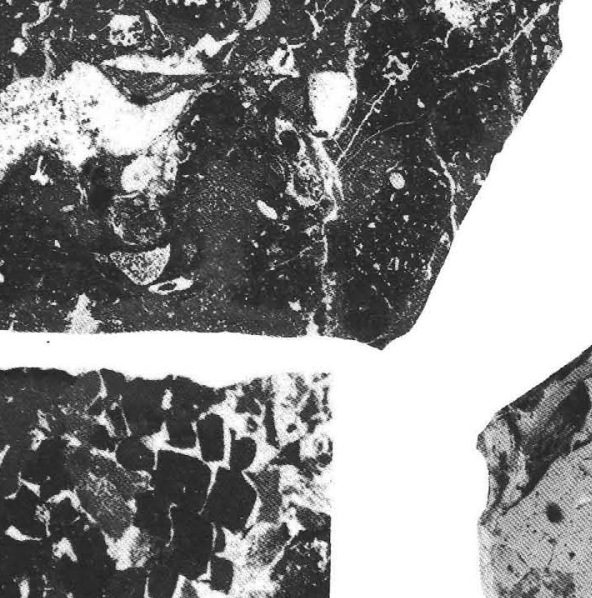
1 1012 (2) $\$$
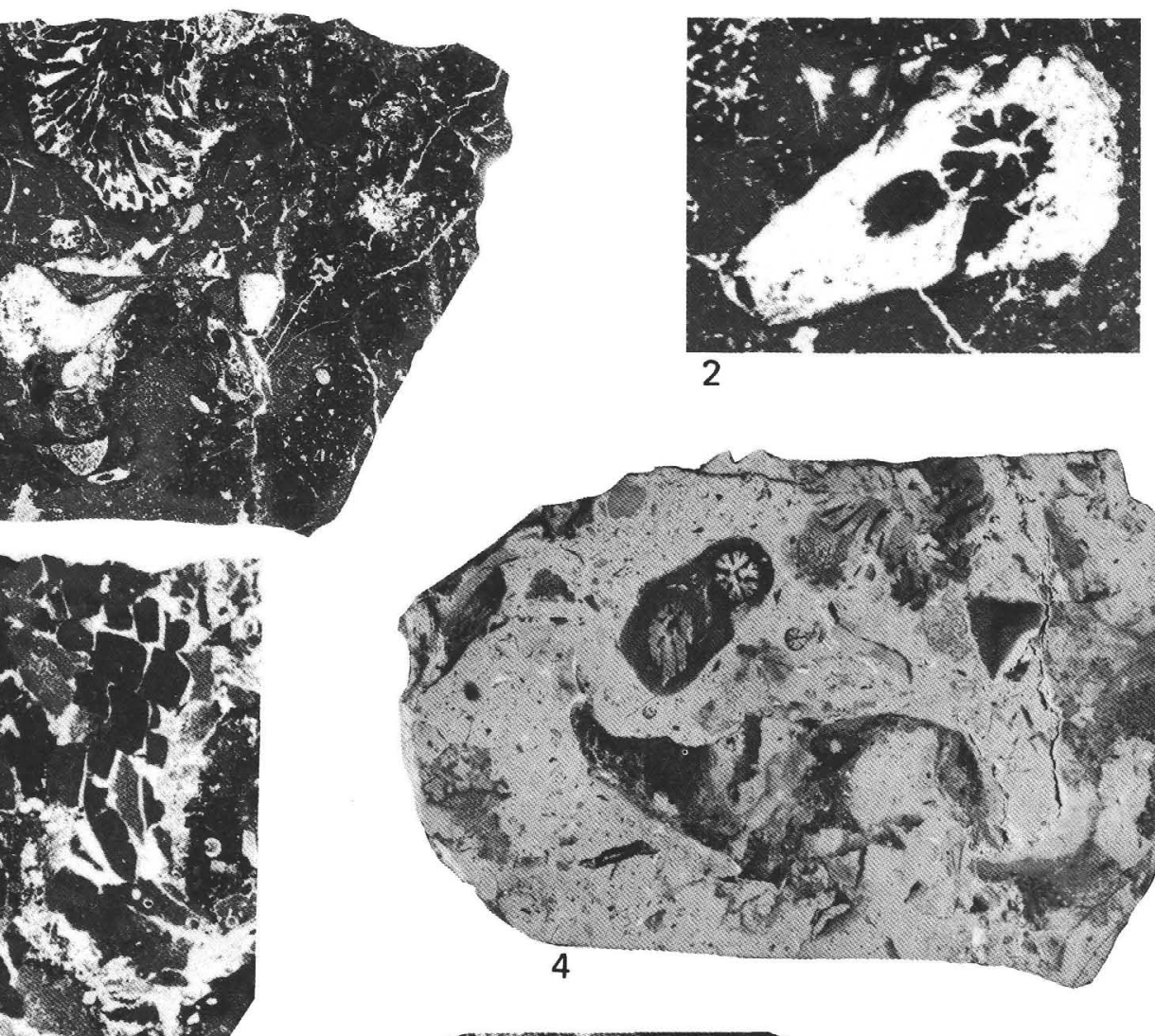

2
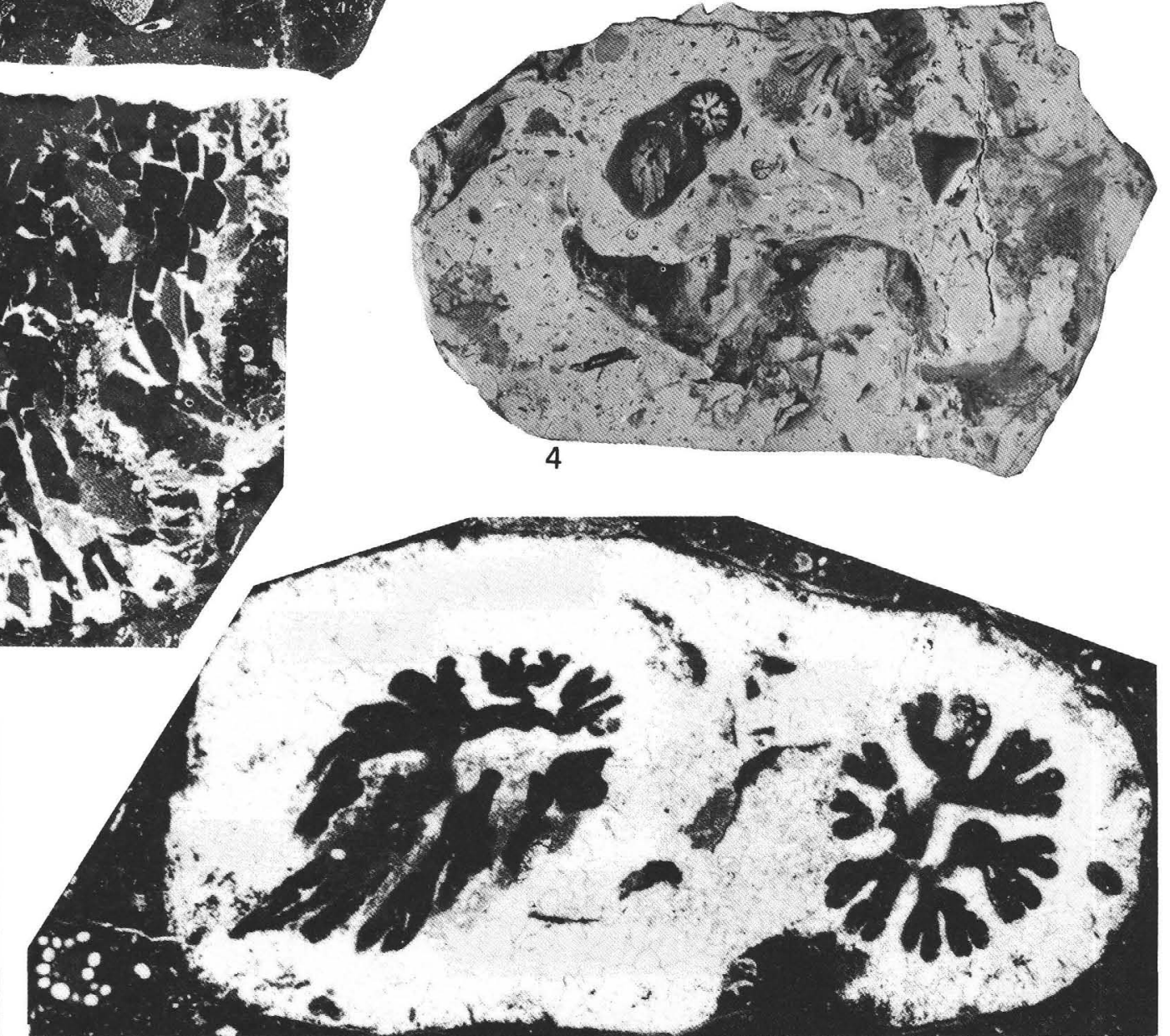

5

Plate 2. Thin-section photomicrographs and polished core-surface photographs of Sample 103-639D-4R, CC (7-9 cm). 1. Photomicrograph of the entire surface of the thin section. $(2.5 \times)$ 2. Detail from Figure 1 of Enallhelia sp. 1. Plane section is interpreted as section a-a 1 in Plate 5, Figure 11 . $(8 \times)$ 3. Detail from Figure 1 of cf. Thecosmilia sp. The same specimen is seen in another section in Plate 2, Figure 4. ( $8 \times$ ) 4. The polished surface before thin-section processing (shown in Fig. 1). $(2.5 \times)$ 5. The thin section made from the core in Figure 4. Enallhelia sp. 1. This thin section follows the one shown in Figure 2. The section plane is interpreted as level b-b in Plate 5, Figure 11. $(15 \times)$ 6. Detail of the thin section made from the core surface shown in Figure 4. Lochmaeosmilia sp. $(25 \times)$ 


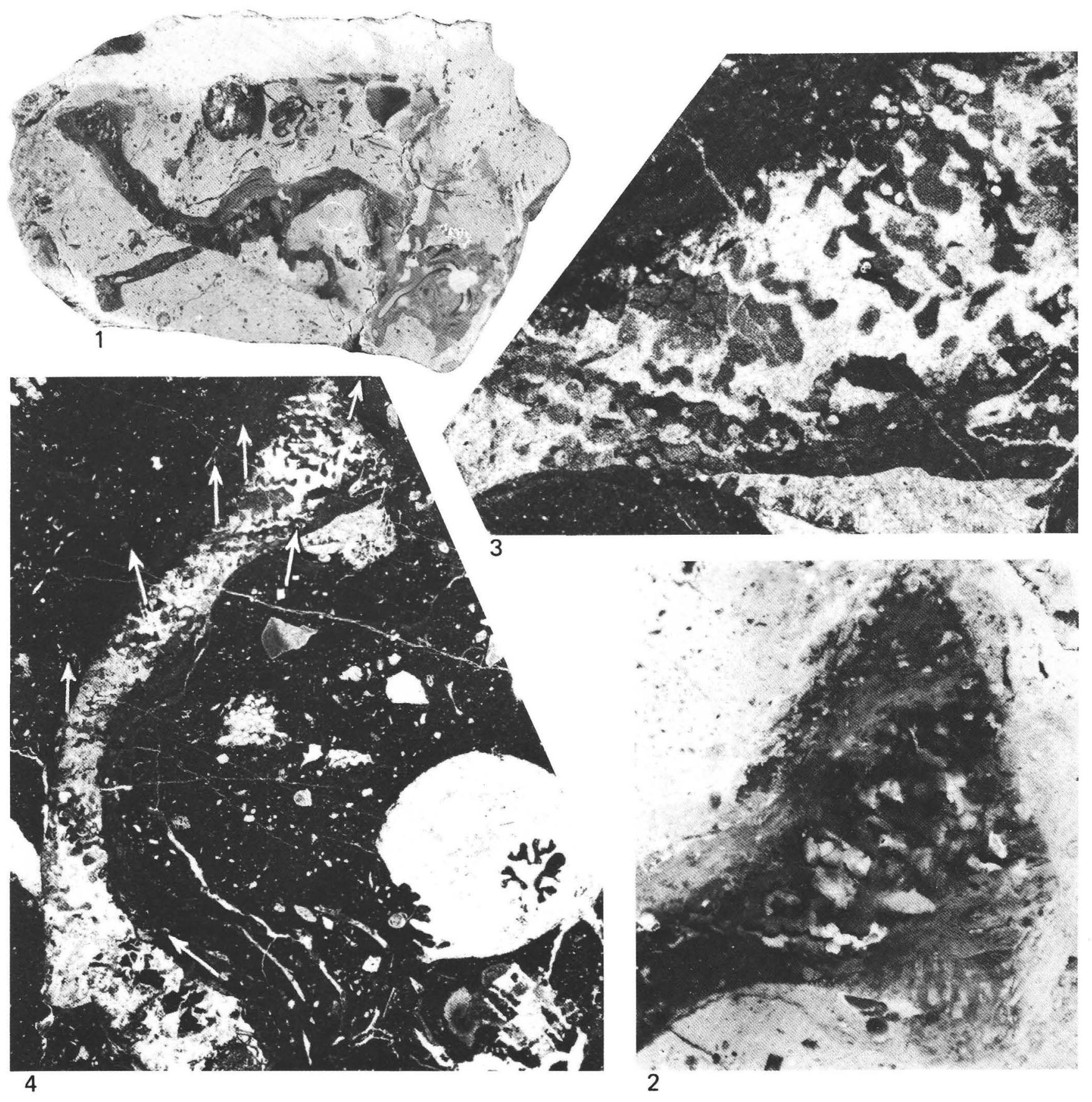

Plate 3. Sample 103-639D-4R, CC (7-9 cm). The polished surface shown in Figures 1 and 2 was processed into the thin-section views in Figures 3 and 4. 1. Polished surface following the surface shown in Plate 2, Figure 4. $(2.5 \times)$ 2. Detail of Microsolena sp. 1. in Figure 1 showing concave pennular rims united as dark rows of "bananas." Other parts of the skeleton are not discernible because the section is parallel to the calcite c-axis. $(15 \times)$ 3. Thin section of the same view in Figure 2. All of the skeletal parts appear transparent. $(25 \times)$ 4. Details of the polished surface in Figure 1, now in thin section. On the left is part of the elongated Microsolena sp. 1, which is also shown in detail in Figures 2 and 3. The colony's growth directions (marked by white arrows) indicate that the coral was heavily carved (by borers?) in situ and was not subjected to transport or wave action. On the right is a third level of the Enallhelia sp. 1 in Plate 2, Figures 2 and 5. The left-hand calice appears to be obliterated, but this is only a result of the section plane, which is comparable to section $\mathrm{c}^{-c_{1}}$ in Plate 5, Figure 11, and not its actual condition. $(8 \times)$ 


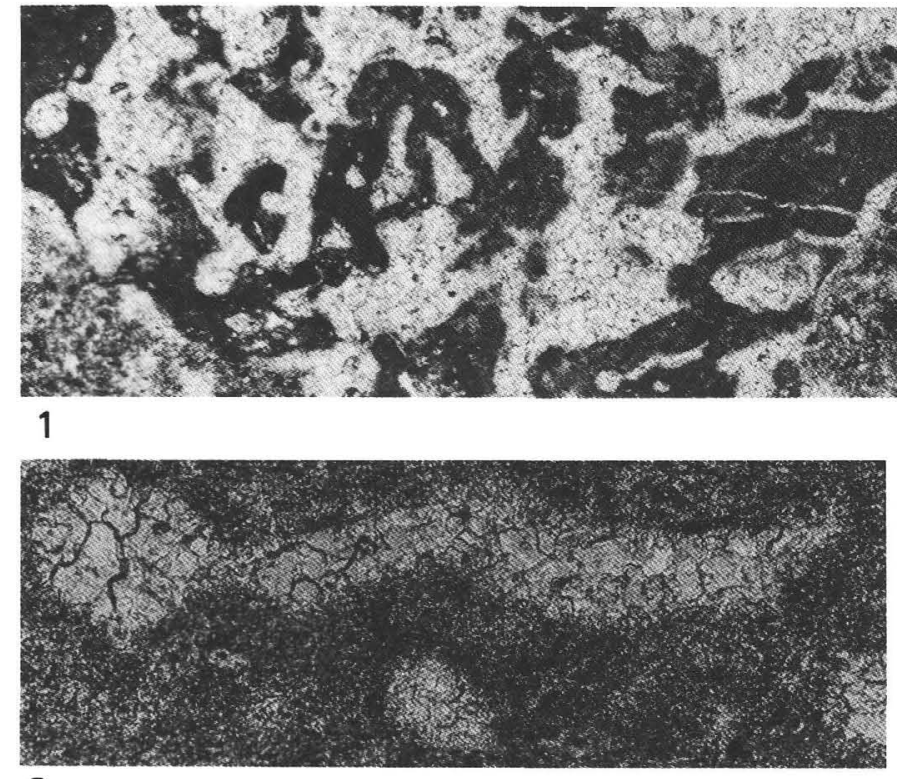

2

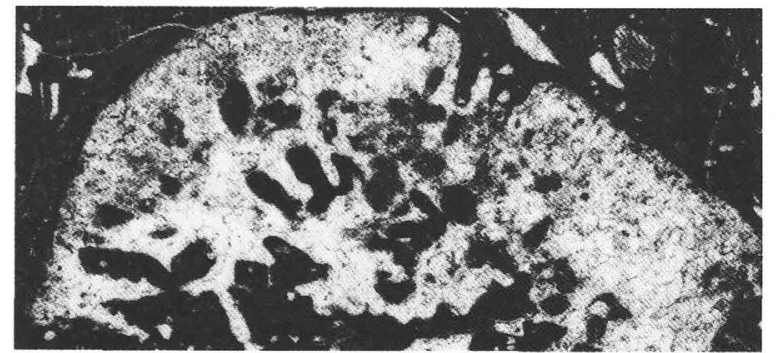

6

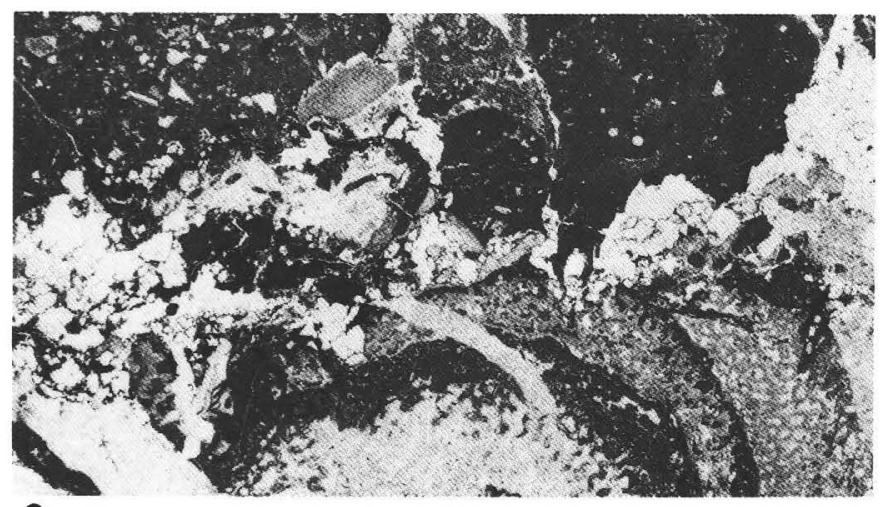

9

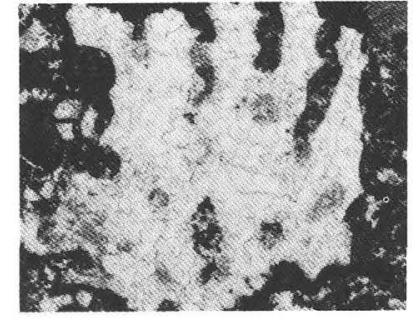

3

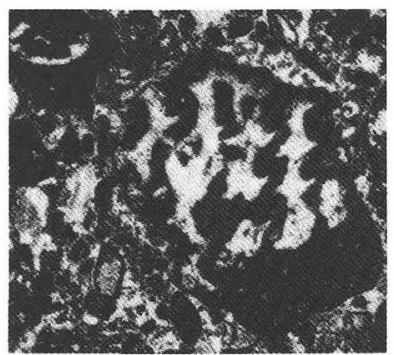

7

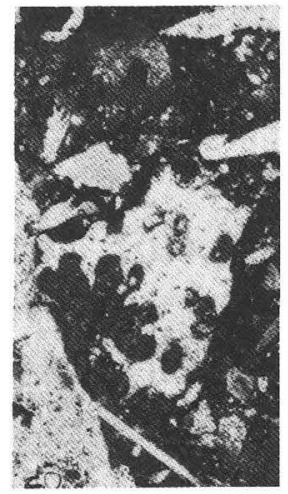

8

5

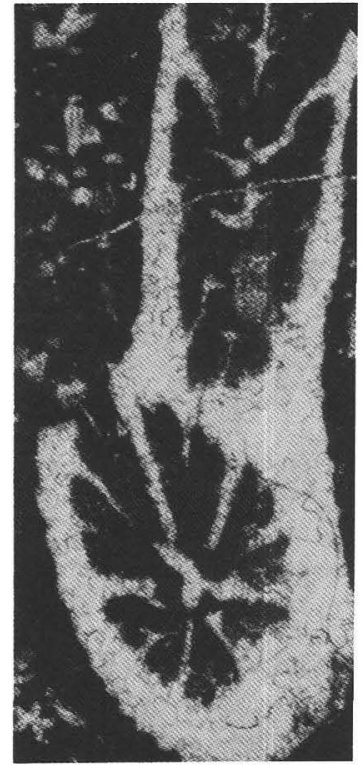

4

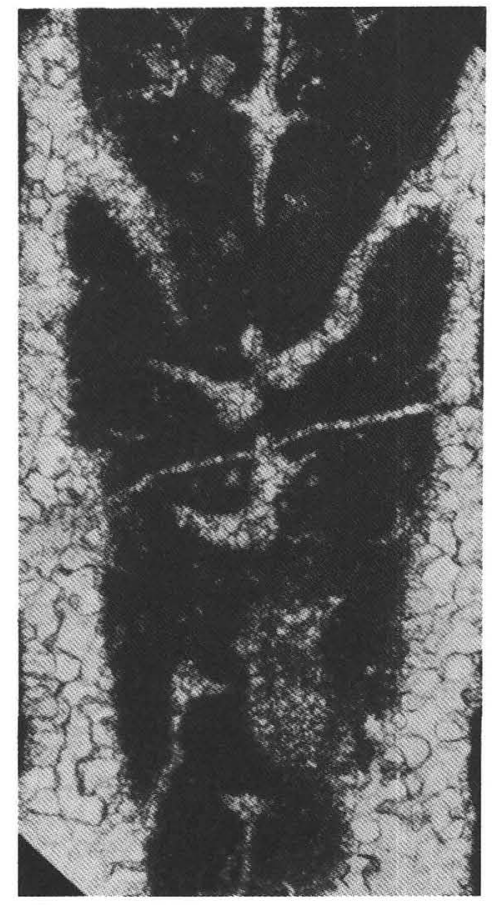

Plate 4. Thin-section photomicrographs. 1. Sample 103-639D-5R-1 (Piece 4, 26-29 cm) showing details of Microsolena sp. 2. This section is also shown in Plate 5, Figure 10. Skeletal elements are cut in various planes. $(30 \times)$ 2. Detail of Figure 1, showing two joined concave pennular rims and two circular sections of synapticulae. $(250 \times)$ 3. Cf. Dimorphastraea sp. in Sample 103-639D-5R-2, 62-70 cm. (15×) 4. Sample 103-639D-5R-2, 97-99 cm. Enallhelia sp. 2. The section plane that of section $\mathrm{d}_{-} \mathrm{d}_{1}$ in Plate 5, Figure 11. The lower calice shows an elongated columella, claviform septal inner ends, and traces of costae on the lower-left outer edge. The upper calice, in longitudinal position, shows the tapering of the wall and claviform and arrowlike sections of the auriculae. $(16 \times)$ 5. Detail of Figure 4. Note the two arrowlike auriculae sections in the upper portion of the photo. $(40 \times)$ 6. Sample 103-639D-5R-2, 60-62 cm. Cf. Dermosmilia sp. (10×) 7. Sample 103-639D-5R-2, 62-70 cm. Latomeandrid coral. $(15 \times)$ 8. Sample 103-639D-5R-2, 63-65 cm. Pseudocoenia sp. $(15 \times)$ 9. Sample 103-639D-5R-3, $42-44 \mathrm{~cm}$. A pennular coral forms the base for successive encrustations. $(5.5 \times)$ 


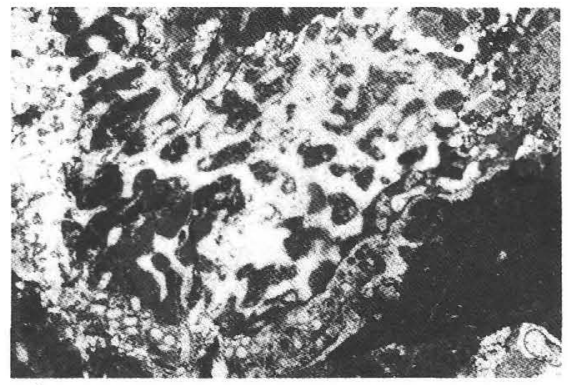

1

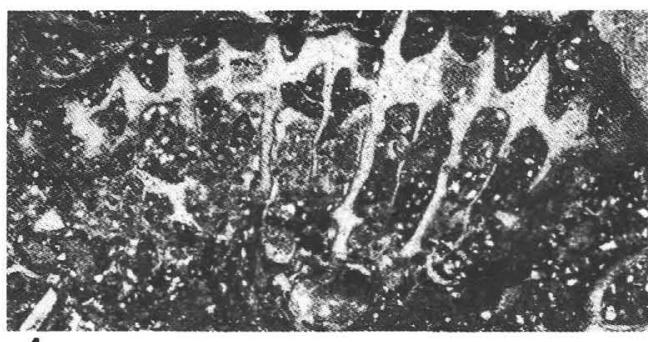

4

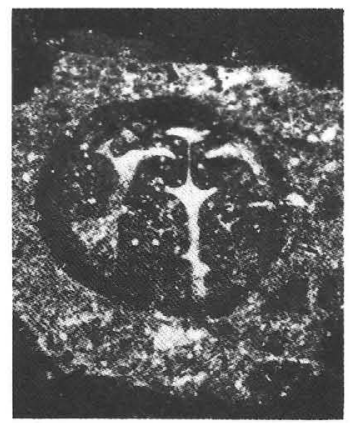

6

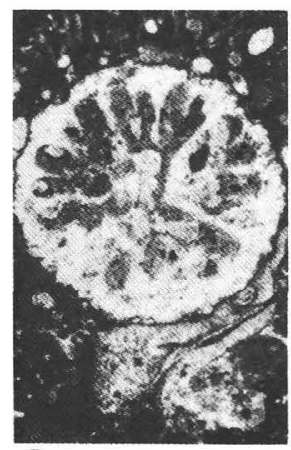

9

10

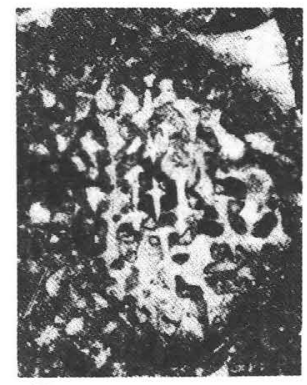

2

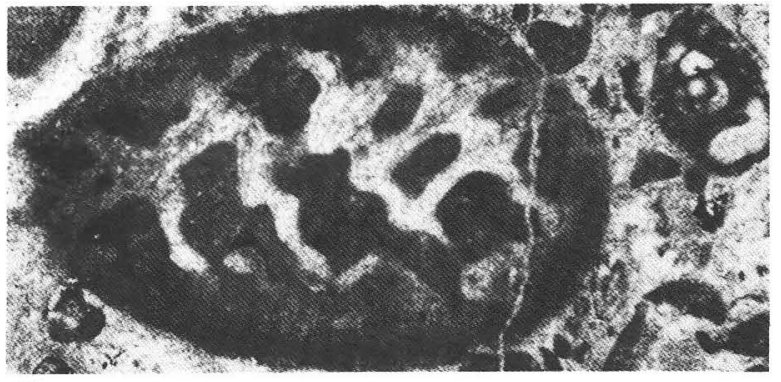

3

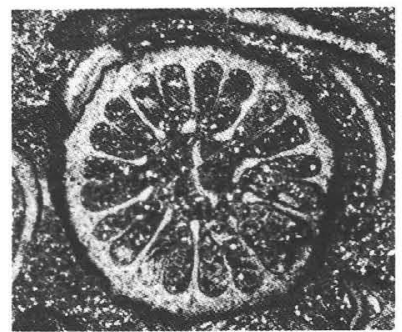

5

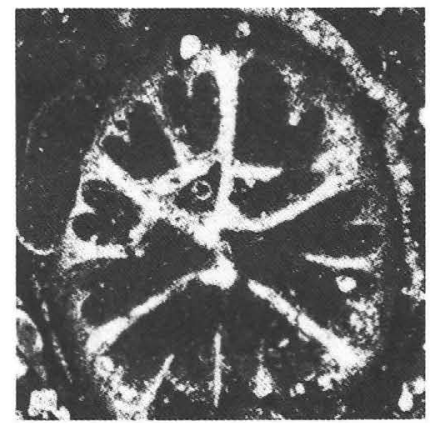

8

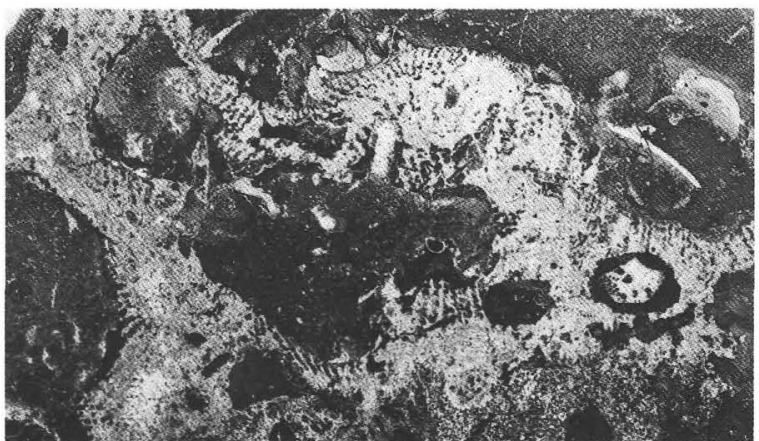

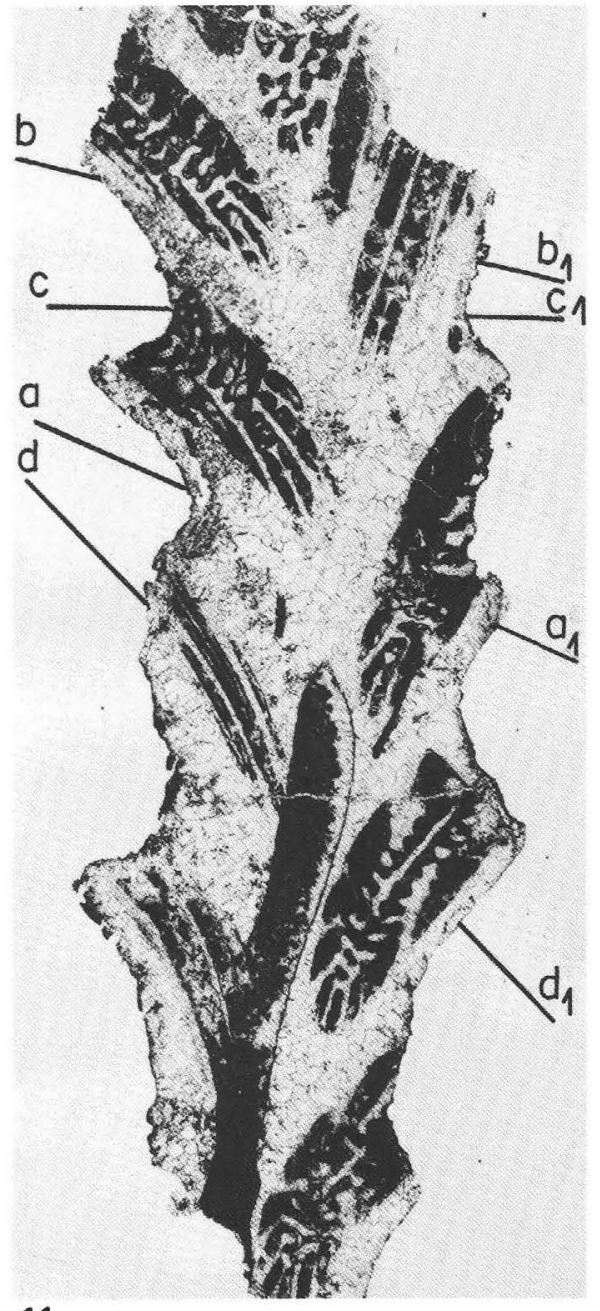

11

Plate 5. Thin-section photomicrographs. 1. Sample 103-639D-5R-2, 94-97 cm. Pennular coral. (10×) 2. Sample 103-639D-5R-3, 42-44 cm. Cf. Calamoseris(?) in a mud-coated grain. (10X) 3. Sample 103-639D-7R-1, 71-75 cm (47). An oval micritized grain of a microsolenid fragment. $(30 \times)$ 4. Sample 103-639D-8R-1 (Piece 3, 15-19 cm). Cf. Calamophylliopsis? (15×) 5. Sample 103-639D-8R-1, 25-29 cm. Stylosmilia sp. 1. (10×) 6. Sample 103-639D-11R-1, 80-89 cm. Stylinid coral. $(15 \times)$ 7. Sample 103-639D-13R-1, 117-120 cm. Cf. Stylosmilia? (10×) 8. Sample 103639D-13R-1, 128-133 cm. Intersmilia sp. (15×) 9. Sample 103-639D-13R-1, 142-146 cm (77). Cf. Stylosmilia sp. 2. (15×) 10. Sample 103-639D-5R-1 (Piece 4, 26-29 cm). Microsolena sp. 2. Colony is heavily bored but does not seem to be transported. Details of this thin section are in Plate 4, Figures 1 and 2. Another section of the same colony is shown in Plate 1, Figure 5. (2.5 $)$ 11. Enallhelia sp. from the middle Callovian of Hamakhtesh Hagadol (Hathira anticline), Negev, Israel. This longitudinal section is marked to assist in interpretation of section planes of Enallhelia in Cores 103639D-4R and 103-639D-5R (Pl. 2, Figs. 1, 2, 4, and 5, Pl. 3, Fig. 4, and Pl. 4, Figs. 4 and 5). An axial boring runs along the lower half of the branch. $(8 \times)$. Coll. G. Gill, M.N.H.N., Paris. 


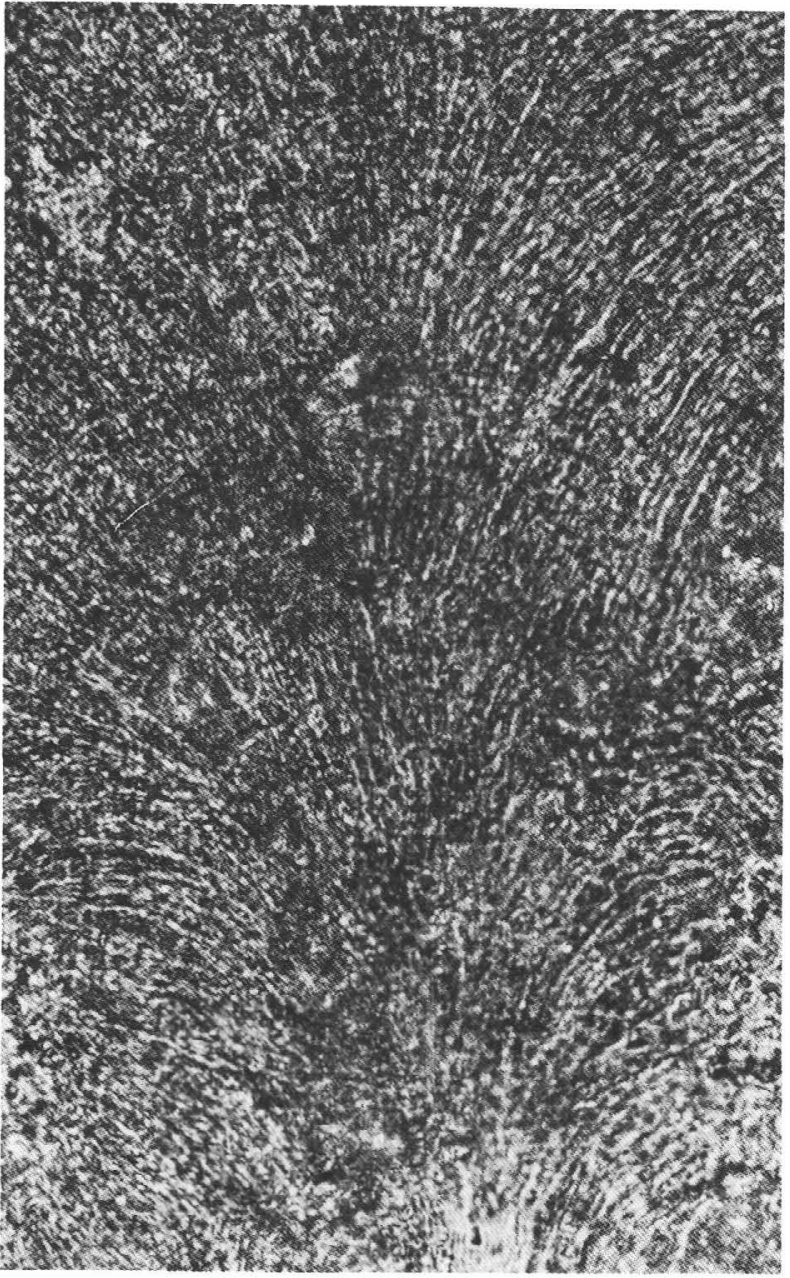

1

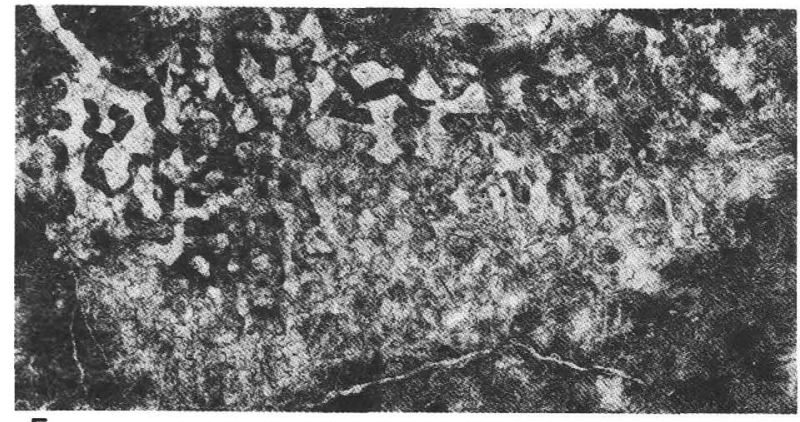

5

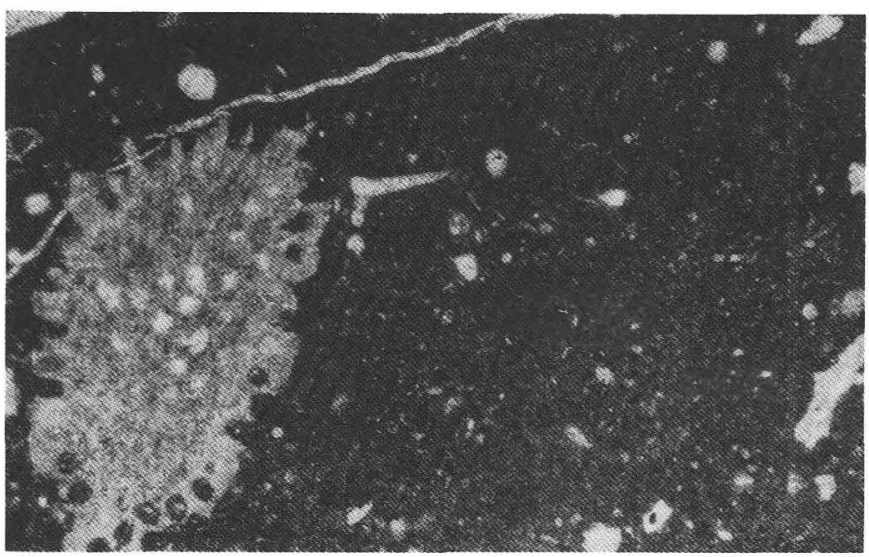

2

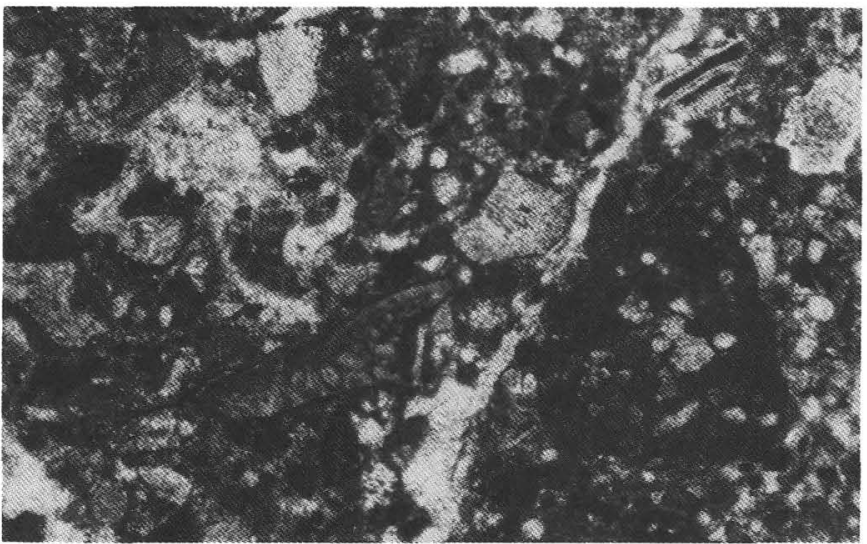

3

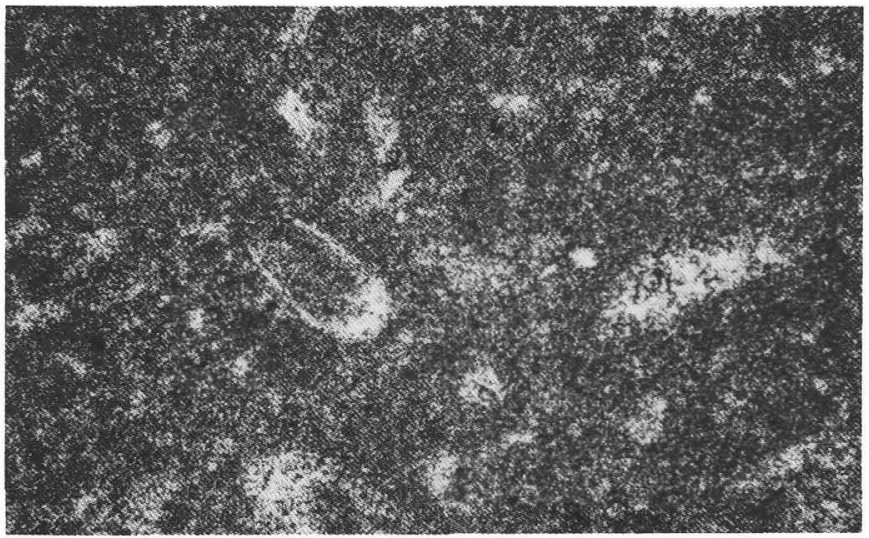

4

Plate 6. Thin-section photomicrographs. 1. Sample 103-639D-5R-2 (Piece 12, 75-77 cm). Chaetetidae with fibrous microstructure preserved in calcite. $(500 \times)$ 2. Sample 103-639D-4R-1, 42-44 cm, with matrix consisting of a slightly micritic structure with fine microscopic debris and calcitized spicules of siliceous sponges. On the left is a larger section of a Chaetetid calcareous sponge. $(25 \times)$ 3. Sample 103-639D-5R-3, 13-16 cm. Matrix is micrite rich in fine debris, micropellets, and calcispheres and showing a bioclastic micropackstone structure. Larger debris includes echinoderms, calcareous sponges (Pharetrones), and bivalves. (25×) 4. Sample 103-639D-5R-2, 188-120 cm. Matrix type with a clotted micritic structure and fine microsparitic debris and calpionellids. $(140 \times)$ 5. Sample 103-639C-2R-2, 69-72 cm (20). A microsolenid remnant that has undergone various stages of dolomitization. $(8 \times)$ 